\title{
Lactic Fermented Fruit or Vegetable Juices: Past, Present and Future
}

\author{
Cyrielle Garcia *D, Marie Guerin, Kaies Souidi and Fabienne Remize $\mathbb{D}$ \\ Qualisud, Univ La Réunion, CIRAD, Univ Montpellier, Montpellier SupAgro, Univ Avignon, 2 rue Wetzell, \\ F-97490 Sainte Clotilde, France; marie.guerin15@gmail.com (M.G.); kaies.souidi@univ-reunion.fr (K.S.); \\ fabienne.remize@univ-reunion.fr (F.R.) \\ * Correspondence: cyrielle.garcia@univ-reunion.fr; Tel.: +33-789-74-97-03
}

Received: 14 December 2019; Accepted: 28 January 2020; Published: 11 February 2020

\begin{abstract}
Numerous traditional low-alcohol fermented beverages produced from fruit or vegetables are described around the world. Fruit and vegetables and lactic fermented products both present nutritional benefits, which give reasons for the recent expansion of non-dairy lactic fermented juices on the market. In addition, fruit and vegetable juices are new carriers for probiotic bacteria. Specific phenotypic traits of lactic acid bacteria (LAB) are required so that LAB can effectively grow in fruit or vegetable juices, increase their safety and improve their sensory and nutritional quality. From the diversity of microbiota of spontaneous fermentations, autochthonous starters can be selected, and their higher performance than allochthonous LAB was demonstrated. Achieving long-term storage and constant high quality of these beverages requires additional processing steps, such as heat treatment. Alternatives to conventional treatments are investigated as they can better preserve nutritional properties, extract bioactive compounds and promote the growth and metabolism of LAB. Specific processing approaches were shown to increase probiotic viability of fruit and vegetable juices. More knowledge on the metabolic activity of lactic acid bacterium consortium in fruit or vegetable juices has become a bottleneck for the understanding and the prediction of changes in bioactive compounds for functional beverages development. Hopefully, the recent developments of metabolomics and methods to describe enzymatic machinery can result in the reconstruction of fermentative pathways.
\end{abstract}

Keywords: probiotic; starter; nutritional quality; microbiota; processing

\section{Introduction}

Traditional fermented foods and beverages have been made for centuries in many regions of Europe, Asia, America and Africa. These foods are produced by ethnic people using their native knowledge from locally available raw materials. Based on the raw material employed, nine groups of fermented foods can be distinguished: fermented cereals, vegetables, legumes, roots/tubers, milk, meat and fish products, miscellaneous fermented products and alcoholic beverages [1]. Nowadays, fermented foods and beverages are obtained through spontaneous fermentation or by starter or probiotic addition. Addition of active bacterial cultures can be considered by the consumer as an added value and a marker of high quality. Historically, the use of probiotics in dairy beverages has been widely investigated, whereas it was less documented in other matrices.

Dietary guidelines around the world recommend increasing the intake of fruit and vegetables for the prevention of chronic diseases. Fruit and vegetables are naturally rich in carbohydrates, dietary fibers, vitamins minerals, polyphenols and phytochemicals [2]. Single-fruit or blend purées, smoothies or juices, that can be probiotic enriched or fermented, are a way to promote the consumption of fruit and vegetables. 
Lactic acid bacteria (LAB) metabolize different substrates, leading to biochemical changes in composition [3]. Lactic acid fermentation is recognized to improve nutritional properties, flavor, and health-related aspects of food products [4]. This process improves the organoleptic properties of food matrixes and their acceptability on top of shelf-life properties [4,5].

Domestication of microorganisms induced genetic changes which reflect adaptation to the food matrix [6-8]. Lactic acid fermentation of fruit is less widespread than milk fermentation and probably requires a specific adaptation of LAB. Some research has been conducted to investigate the suitability of various fruit and/or vegetable beverages as raw substrates to the lactic acid fermentation. The most common genera used were Lactobacillus, Leuconostoc, Weissella and Bifidobacterium, obtained commercially or isolated from plants. These bacteria share the ability to produce lactic acid, and in a strain-dependent way, aromatic compounds, exopolysaccharides, bacteriocins, and enzymes implied in the increase in food safety and shelf life [9]. However, each species presents its own characteristics and produces miscellaneous effects depending on the substrates and process applied.

Several factors must be considered for the selection of candidate LAB for fermented fruit or vegetable juice elaboration. LAB capacity to grow and acidify the juice must be ensured, together with the increase in safety by elimination of pathogens and absence of biogenic amine production. The effects of lactic acid fermentation on sensory and nutritional quality should be determined [10]. Starter strains must also satisfy several criteria such as good yields and viability for starter production or manufacturing, administration and application. Survival and colonization in the host is a prerequisite for LAB to be considered as probiotic [11].

In this article, we examine the literature on traditional fruit and vegetable fermented beverages and new trends, with regards to the characteristics of LAB diversity, the impact of processing steps, and the reputed nutritional and health benefits. Recent achievements with "omic" tools are shown to be powerful to increase knowledge for the successful development of promising functional beverages.

\section{Actual Market}

The global functional beverage market is a growing sector of the food industry as modern health-conscious consumers show an increasing desire for foods that can improve well-being and reduce the risk of disease. It was reported that the market of functional foods was the fastest-growing sector, with an expected annual growth of $10 \%$ compared to $2 \%$ to $3 \%$ for the food industry in 2008 [12]. Within the range of new functional foods, an important segment is composed of beverages elaborated from cereal, legume, tuber and fruit. The functional beverage market was distinctly the fastest growing segment at the same time, evolving and growing at different rates both within and across Countries, with a noticeable annual growth of $14 \%$ in particular in the U.S. between 2002 and 2007 [12]. These products have become significant in the context of a greater prevalence of lactose intolerance, and the preference for low cholesterol products, leading consumers to avoid dairy beverages [13].

The position of lactic fermented beverages benefits from the presence of probiotics bacteria and it is to highlight that among probiotic foods, the ones containing fruit ingredients are increasingly preferred by consumers [14]. These drinks meet a growing demand for less sugary products. Especially as the reaction against sugar is driving a change in flavor preferences across Europe, with sour, bitter or tangy flavor being more popular. A telling example is the 1st price of innovation from the last SIAL world food exhibition in 2018 being awarded to a Greek fruit and water kefir [15].

Further, the application of fruit as substrates for lactic fermentation has the advantage of the incorporation of flavors and nutrients specific to each type of fruit, resulting in products with differential sensory and physicochemical characteristics, appreciated by consumers. A comparison of beverage formulations made from different fermented Brazilian fruits, with the addition or not of whey, shows that the addition of dairy ingredients is not desirable, and that the consumers preference is lactose-free fermented fruit juices [16].

We explored the scientific literature on fermented beverages by bibliometrics on the Science Direct database to quantify the interest for this topic during the last 20 years. A low number of scientific 
publications for fermented beverages until 2005 (Figure 1) was observed, but then the interest in exploration of this process was progressively and noticeably growing. The topic exceeded the threshold of 250 original research articles per year in 2011, 500 in 2016, and is now above 700 while the count reached 937 for the total publications. A focus on fruit and vegetable fermented beverages showed a moderate scientific production reaching only 100 original research articles per year in 2012 but then the number of publications was doubled in 2017 and is now 384 for the total publications.

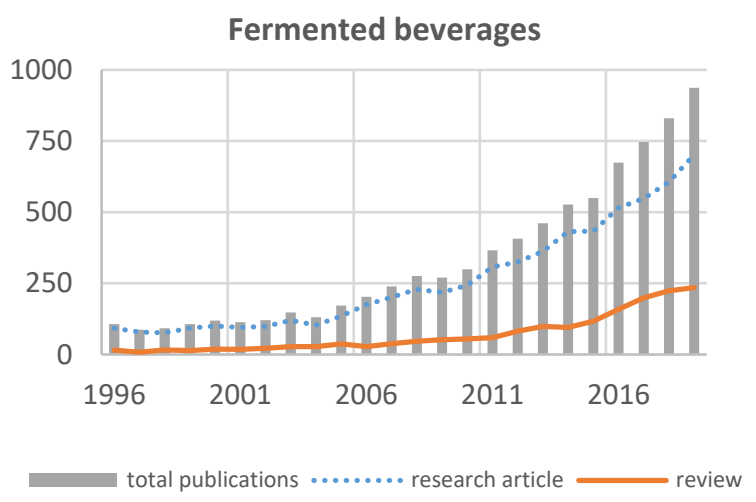

(a)

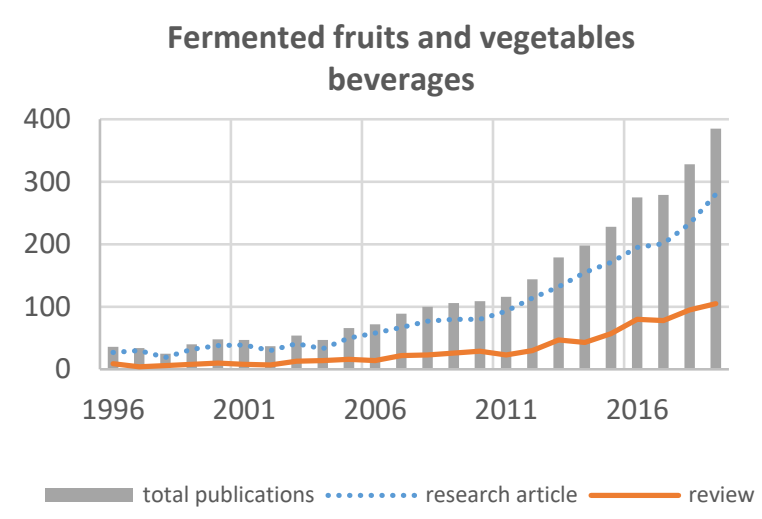

(b)

Figure 1. Publication trends per year on fermented beverages (a) and fruit and vegetable fermented beverages (b) according to the Science Direct database.

Scientific interest is growing for beverages such as fermented fruit and vegetable juices, as they seem to be new adapted carriers of probiotic bacteria, winning consumer preference and leading to developing products with a specific taste.

\section{Traditional Lactic Fermented Beverages}

The elaboration of fermented beverages with health-promoting properties from milk, cereals and other substrates is traditional for centuries in many regions of Asia, Africa, Europe, the Middle East and South America. An important class of non-dairy fermented beverages was those made from cereals, popular in tropical regions and in Africa in particular [17]. Traditional African fermented products include fermented milks, sour porridges, and alcoholic and non-alcoholic beverages. African traditional fermented beverages are mainly made with cereals of cassava, maize, sorghum and millet. These products are fermented using mainly LAB, such as Lactobacillus. sp., Bacillus sp., Pediococcus sp. and Weissella sp., and yeasts [11].

Moreover, some lactic fermented beverages are traditionally produced from fruit or vegetables in specific areas, such as Turkey [18,19] or Albania and Kossovo [20]. Most fruit-based non-alcoholic or low-alcoholic traditional beverages are made by complex microbiota associating yeasts, LAB and acetic acid bacteria. This applies to water kefir or sugary kefir.

Water kefir is made from water, sugar and dried fruit, fermented with kefir grains containing a microbial consortium surrounded by a polysaccharidic matrix, named kefiran. This consortium is steady or stable for years [21]. In commercial water kefir grains available on market, Zymomonas mobilis was shown to be the dominating bacteria, representing up to $87 \%$ of bacteria [13]. Water kefir microbiota examination is recent, compared to milk kefir. Research mainly focused on grains, and few data are available on possible changes concerning the ecosystem diversity over fermentation and storage of the products [22,23]. However, the microbial diversity relies more upon grain origin and between grain and beverage, rather than changes over fermentation time [22-24].

Kombucha is a fermented black tea beverage in which sugar has been added. Like water kefir, it is fermented through a complex ecosystem made of yeasts, acetic acid bacteria and LAB. 
But this consortium is embedded in a cellulosic mat and the fermentation is dominated by yeasts, especially Zygosaccharomyces or Candida and Lachancea depending on Kombucha origin, and acetic acid bacteria $[17,25]$. Acetic acid bacteria represent $60 \%$ to more than $90 \%$ of bacteria [17]. Lactobacillus, Leuconostoc and Lactococcus are present in the first fermentation stages, although at low levels $(<5 \%)$. However, by the end of fermentation process, during which $\mathrm{pH}$ decreases, Lactobacillus species may represent up to $10 \%$ of bacteria and reach $30 \%$ in the mat pellicle [17].

Other traditional fermented beverages made from fruit and vegetables can be found in Turkey. They are named Shalgam juice and Hardaliye [18]. Shalgam juice is made from a mixture of black or purple carrot (Daucus carota) slices, turnip (Brassica rapa) slices and wheat flour in salted water. After fermentation and filtration, a red-colored cloudy beverage is obtained. This juice has a sour taste and is rich in minerals ( $\mathrm{Ca}, \mathrm{K}$ and $\mathrm{Fe}$ ), vitamins ( $\mathrm{A}, \mathrm{C}$ and $\mathrm{B}$ group vitamins) and polyphenols. Its microbiota is mainly composed of yeasts and Lactobacillus (89.63\%), Leuconostoc (9.63\%) and Pediococcus $(0.74 \%)$. Hardaliye is prepared from grapes, mustard seeds and cherry leaves and is fermented mainly by Lactobacillus spp. Also, in Turkey, Gilaburu juice is made using water and European cranberry bush (Viburnum opulus L., gilaburu in Turkish), a red-colored fruit with an astringent taste. The LAB identified include Lactobacillus spp. and Leuconostoc spp. [26].

Soymilk is traditionally made in Asia from a water extract of soybeans which is fermented using five LAB species, namely Lactobacillus casei, Lactobacillus acidophilus, Streptococcus thermophilus, Lactobacillus bulgaricus, Bifidobacterium longum. This product is used as an antioxidant, a probiotic, in treatment of breast cancer and to maintain intestinal environment [9].

Sauerkraut juice is obtained by white cabbage fermentation using the same process as for making sauerkraut meal. This beverage is consumed in Germany, Ukraine, Romania, Serbia and other regions in the Black Sea. The LAB involved in this process are Lactobacillus brevis, Lactobacillus sakei, Lactobacillus plantarum and Leuconostoc mesenteroides [26].

\section{Recently Developed Lactic acid Fermented Juices}

\subsection{Overview}

Beyond products rooted in tradition, the development of new lactic fermented fruit or vegetable juices has recently generated interest. These products have been shown to have considerable market value, because of the combination of nutritional advantages of the raw materials and benefits resulting from lactic fermentation [27-33]. Some attempts to develop lactic fermented fruit or vegetable juices have been made on various substrates. To achieve these fermentations, water kefir grains have been occasionally used. However, most studies were performed with Lactobacillus spp., and some with Bifidobacterium spp., Leuconostoc spp. or Weissella spp.

To be successful, the manufacturing process of these beverages requires a mild pasteurization and inoculation with selected starters [34]. Pasteurization reduces microbial population in the juice, possibly inactivates foodborne pathogens, and hence favors the implantation of the starter. To obtain a well-accepted beverage, the sensory characteristics have to be carefully examined, by adjustment of the mix of fruit or vegetables, to avoid an unpleasant acidic or astringent beverage, and by the choice of starters to avoid undesirable compounds, flavors or biogenic amines.

The ability of starter strains to grow in the juice is an important parameter to consider for successful fermentation or to expect some probiotic effects [14,30,35-39]. Long-term survival of bacteria in the fermented juice and putative probiotic properties of starters in the beverages are regarded as advantages [40,41]. For instance, a 1000× population decrease was observed after four weeks of storage in fermented tomato juice for L. plantarum, whereas a similar effect was observed for L. acidophilus in red beet juice and Lactobacillus delbrueckii in cabbage juice [37-39]. Some factors, such as low temperature and the presence of sugars, favor survival in an acidic medium [42,43].

Therefore, it is recommended to isolate autochthonous starters from fruit or vegetable carposphere or from spontaneous fermentations as those isolates exhibit specific phenotypic traits [28,44-48]. 
For instance, Lactococcus lactis isolates from dairy environment greatly differ in their genes from environmental strains [49], showing domestication of strains. As a consequence, their phenotype reflects their adaptation to a specific niche [50,51]. Similar exploitation of genomic data, through comparative genomics, have been performed with L. plantarum and Fructobacillus spp. [52,53].

From literature data, it appears that the bacterial strain-food material combination determines the bacterial growth characteristics, sensory properties of the fermented food and changes in bioactive compounds. The nature, content and structure of bioactive compounds is specific to each raw material. These features can be modulated by processing and microbial metabolism.

\subsection{Juices Stabilization Treatments}

\subsubsection{Conventional Thermal Treatment of Juices}

Fruit and vegetable juices are generally preserved by physical, chemical or biological processes prior to consumption and utilization. These processing steps aim to ensure safety and to maintain the quality of products which can be affected by enzyme activity or chemical reactions. The efficacy of processing is impacted by the complexity of composition of juices and their microbial diversity, which trigger the choice of process and process parameters. Thermal and non-thermal processes with various intensities are the most commonly used methods in the processing of fruit and vegetable juices prior to their fermentation.

Table 1 provides a comprehensive summary of the outputs of processing treatments applied to fruit and vegetable juices prior to fermentation, or cold storage of treated and fermented juices. Processing treatments comprise mainly heat treatments, but also treatments with alternative technologies. 
Table 1. Process parameters for lactic fermentation of fruit and vegetable juices.

\begin{tabular}{|c|c|c|c|}
\hline Processing Conditions & Raw Material & Outputs & Reference \\
\hline \multicolumn{4}{|c|}{ Thermal Treatments Prior to Fermentation } \\
\hline $\begin{array}{l}\text { Sterilization }\left(120^{\circ} \mathrm{C} / 5 \mathrm{~min}\right) \text {; fermentation }\left(30 \text { or } 37^{\circ} \mathrm{C}\right) \\
\text { Lactobacillus fermentum and Lactobacillus casei; cold storage } \\
\text { (4 weeks) }\end{array}$ & Watermelon and tomato & $\begin{array}{l}\text { Different survival of bacteria during the cold storage period } \\
\text { depending on fermentation temperature }\end{array}$ & [54] \\
\hline $\begin{array}{l}\text { Homogenization; heating }\left(100^{\circ} \mathrm{C} / 5,30,60,90 \text { and } 120 \mathrm{~min}\right) \text {; } \\
\text { fermentation (Bifidobacterium brevis, Bifidobacterium longum, } \\
\text { and Bifidobacterium infantis) }\end{array}$ & Fresh tomato & $\begin{array}{l}\text { No heating impact on } \mathrm{pH} \text {, Brix, acidity of juice; redness } \\
\text { increases until } 60 \text { min heating; heating increases lycopene } \\
\text { content; fermentation did not affect lycopene content }\end{array}$ & [55] \\
\hline $\begin{array}{l}\text { Commercial tomato juice (pasteurized); fermentation } \\
\text { (Lactobacillus acidophilus LA39, L. casei A4, Lactobacillus. } \\
\text { delbrueckii D7, Lactobacillus plantarum); storage }\left(4^{\circ} \mathrm{C} / 4\right. \\
\text { weeks) }\end{array}$ & Commercial tomato juice & $\begin{array}{l}\text { Viability of L. acidophilus and L. delbrueckii } \\
\text { did not decrease during cold storage of fermented juice }\left(10^{6}\right. \\
\left.\text { to } 10^{8} \mathrm{CFU} / \mathrm{mL}\right)\end{array}$ & [39] \\
\hline $\begin{array}{l}\text { Extraction; autoclave sterilization }\left(121^{\circ} \mathrm{C} / 15 \mathrm{~min}\right) \text {; } \\
\text { fermentation; cold storage for } 4 \text { weeks }\end{array}$ & Red beets & $\begin{array}{l}\text { The fermented juice contained a significant load of } \\
\text { beneficial viable cells for LAB }\left(10^{9} \mathrm{CFU} / \mathrm{mL}\right)\end{array}$ & [37] \\
\hline $\begin{array}{l}\text { Centrifugal juice extractor; pasteurization }\left(75^{\circ} \mathrm{C} / 5 \mathrm{~min}\right) \text {; } \\
\text { fermentation }\left(25^{\circ} \mathrm{C} / 48 \mathrm{~h} \text { ) by commercial water kefir }\right. \\
\text { preparation of } 10^{9} \mathrm{UFC} / \mathrm{mL} \text { containing (Lactobacillus, } \\
\text { Lactococcus, Leuconostoc and Saccharomyces) }\end{array}$ & $\begin{array}{l}\text { Carrots, fennels, melons, onions, } \\
\text { tomatoes }\end{array}$ & $\begin{array}{l}\text { Thermal treatment reduced all microbial groups at levels } \\
\text { below the detection limits; physicochemical and } \\
\text { organoleptic attributes of fermented juice were acceptable; } \\
\text { changes in antioxidant activities }\end{array}$ & [56] \\
\hline $\begin{array}{l}\text { Pre-treatments (filtration connected or not with thermal } \\
\text { treatment and/or enzymatic processing) of juices prior to } \\
\text { fermentation }\end{array}$ & Pomegranate & $\begin{array}{l}\text { A short pasteurization at } 95^{\circ} \mathrm{C} / 30-60 \text { s eliminated all } \\
\text { microorganisms found in juice } \rightarrow \text { Preservation of bioactive } \\
\text { molecules }+ \text { less anthocyanin degradation }+ \text { improved } \\
\text { antioxidant activities; clarification was related to reduction } \\
\text { of phenol content and lower antioxidant activity }\end{array}$ & [57] \\
\hline
\end{tabular}


Table 1. Cont

\begin{tabular}{|c|c|c|c|}
\hline Processing Conditions & Raw Material & Outputs & Reference \\
\hline \multicolumn{4}{|c|}{ Combination between Thermal and Non-Thermal Treatments } \\
\hline $\begin{array}{l}\text { Drying of raw material }\left(40^{\circ} \mathrm{C} / 3 \text { days); sterilization of }\right. \\
\text { powder suspension }\left(121^{\circ} \mathrm{C} / 15 \mathrm{~min}\right) \text {; fermentation by } \\
\text { Bacillus amyloliquefaciens and Lactobacillus brevis separately; } \\
\text { light illumination (LED, sunlight and dark) }\end{array}$ & Blueberry & $\begin{array}{l}\text { Light illumination enhanced metabolic activity + maximal } \\
\text { LAB growth + highest TPC and flavonoids; blue LED } \\
\text { mediated fermentation } \rightarrow \text { an extract with antibacterial } \\
\text { activity only; Red LED mediated fermentation } \rightarrow \text { extract } \\
\text { with antioxidant (phenols and flavonoids) and cytotoxic } \\
\text { activities }\end{array}$ & [58] \\
\hline $\begin{array}{l}\text { Ultrasonicated homogenization }\left(376 \mathrm{~W} / \mathrm{cm}^{2}, 500 \mathrm{~W}, 10 \mathrm{~min}\right) \text {; } \\
\text { of L. casei); fermentation }\left(24 \mathrm{~h} ; 1041^{\circ} \mathrm{C}\right) \text {; cold storage } \\
\left(4{ }^{\circ} \mathrm{C} / 42 \text { days }\right)\end{array}$ & Pineapple & $\begin{array}{l}\text { Ultrasonication of pineapple juice improved LAB viability } \\
\text { and prevented browning; fermented juice exhibited } \\
\text { acceptance for color and sensory evaluation }\end{array}$ & [59] \\
\hline $\begin{array}{l}\text { Heating }\left(95^{\circ} \mathrm{C} / 1 \mathrm{~min}\right) ; \text { High Hydrostatic Pressure: HHP } \\
\left(500 \mathrm{MP} / 2 \mathrm{~min} ; 25^{\circ} \mathrm{C}\right) ; \text { fermentation of } L \text {. casei }\left(10^{5} \mathrm{CFU} / \mathrm{mL}\right)\end{array}$ & Litchi & $\begin{array}{l}\text { HHP fermented juice exhibited better color, flavor and } \\
\text { overall acceptance than heated one; both HHP and Heated } \\
\text { fermented litchi juice showed enhanced cell viability }\end{array}$ & [60] \\
\hline $\begin{array}{l}\text { Bleaching }\left(100^{\circ} \mathrm{C} / 2 \mathrm{~min}\right) \text {, squeezing, filtering; thermal } \\
\text { processing } \mathrm{TP}\left(100^{\circ} \mathrm{C} / 30 \mathrm{~s}\right) ; \mathrm{HHP}(300,400,500 \mathrm{MP} / 15 \mathrm{~min} \text {; } \\
\left.25^{\circ} \mathrm{C}\right) \text {; storage }\left(20^{\circ} \mathrm{C}\right) \text { until use; fermentation }(\text { Lactobacillus } \\
\text { rhamnosus }\left(30^{\circ} \mathrm{C} / 18 \mathrm{~h}\right) \text {, Gluconacetobacter xylinus }\left(30^{\circ} \mathrm{C} / 24 \mathrm{~h} \text {; }\right. \\
160 \mathrm{rpm}))\end{array}$ & Yacon, Litchi and Longan (YLL) & $\begin{array}{l}\mathrm{TP}\left(100^{\circ} \mathrm{C} / 30 \mathrm{~s}\right) \text { and } \mathrm{HHP}(500 \mathrm{MPa} / 15 \mathrm{~min}) \text { of juice } \\
\text { complied with aseptic standards and ensured microbial } \\
\text { safety; TP reduced the taste score of juice and reduced } \\
\text { flavor molecules (alcohols, esters, } \ldots \text { ); HPP preserved the } \\
\text { nutritional and aroma characteristics of juice; fermentation } \\
\text { of HHP juice improved the taste (aminoacids, } \\
\text { carbohydrates, ... ) and flavors of YLL juice; HHP } \\
\text { cofermentation improved the quality of YLL juice }\end{array}$ & [61] \\
\hline
\end{tabular}


The aim of the High-Temperature, Long-Time treatment (HTLT) application is the inactivation of native microflora prior to fermentation. For example, Koh et al. [55] and Sivudu et al. [54] worked on the effect of HTLT of tomato juice alone or mixed to be subject to the fermentation by bifidobacterial species. Authors reported that these conditions of pre-treatment did not seem to affect the physicochemical properties of vegetable juice and were able to maintain viability of LAB cells.

Thermal treatment was evaluated as function of its intensity and time. For example, HTLT ( $T$ $\geq 80^{\circ} \mathrm{C}$ and holding time $>30 \mathrm{~s}$ ) could reduce or inactivate some enzymes, whose activities result in undesirable changes in sensory quality attributes and nutritive value of the products [62], such as polyphenoloxidase, peroxidase, pectin esterase and polygalacturonase [63]. High temperature treatment might present some drawbacks as it affects many antioxidant compounds, thus reducing their beneficial health effects and deteriorate the quality attributes and physicochemical properties.

\subsubsection{Alternative Physical Treatment}

Many studies were carried out on the potential of use of Ohmic Heating $(\mathrm{OH})$ based on electrical current passage in the food processing. This process provides uniform and rapid heating of foods, with a beneficial effect on the nutritional and organoleptic properties of processed products [64]. According to literature reviews [65-67], $\mathrm{OH}$ is a promising alternative to conventional thermal technologies for juice processing with a maximum retention of functional components and the destruction of foodborne microorganisms by electroporation mechanism. A nutritional advantage consisting in the limitation of xanthophyll losses to $20-30 \%$ was reported by Achir et al. in ohmic heated citrus fruit juices, compared losses of $40-70 \%$ with conventional heating [68].

It seems that no studies or at least a few have focused on the $\mathrm{OH}$ treatment for fermented fruit or vegetable-based juices. Taking into account the findings reported by literature, we can assume that $\mathrm{OH}$ treatment can be effectively used to pasteurize fresh fruit or vegetable juices with minimal sensory and functional deterioration prior to their fermentation. Some studies [69] reported that a combination of $\mathrm{OH}$ with moderate electric field is desirable in the food fermentation process to shorten the lag-period and to promote the growth and metabolism of fermentation microorganisms under optimized conditions compared with conventional fermentation. The combination effect of $\mathrm{OH}$ and Ultrasound Irradiation deals in improvement of substrate bioavailability to fermentation process in general.

Another promising non-conventional thermal treatment of fruit and vegetable juices is the microwave heating (MWH). This way presents some benefits, like the reduced processing time, high power efficiency and a good process control for reducing the loss of juices quality as well as destroy harmful pathogenic bacteria [70]. Overall, the effectiveness of $\mathrm{MWH}$ as compared to the traditional treatment is confirmed by: the high total phenols and flavonoid compounds in watermelon, black jamun, litchi, grapefruit and pineapple juices [71]; the preservation of physicochemical properties in tomato juice [72] and many juice-blends [73]; the significant retention of ascorbic acid and the preservation of color and rheological properties in guava nectar [74]. The study of Pérez-Grijalva [75] highlights the potential application of microwaves and ultrasound to increase the functional value of blackberry juice. Authors reported that microwaves in combination with ultrasound technologies present an alternative in fruit juices processing when the antioxidant activity is high, and the microbial quality is good. Some drawbacks related to $\mathrm{MWH}$ include the formation of colored decomposition products (browning) in beetroot juice [76] and the decrease in $\mathrm{pH}$ and color values in pomegranate juice.

Thermosonication is another good alternative technique to replace the conventional heat treatment process. It has potential in enhancing quality, safety and yield extraction of fruit and vegetable juices [77]. This process is able to inactivate the enzymes and destroy the microorganisms at lower temperature and shorter time to give lower losses of ascorbic acid, total phenolics, flavonoids and flavonols [78]. Pulsed electric field treatment is also an alternative, tested on whole citrus fruit (orange, pomelo, and lemon) in aqueous media to increase yield extraction and phenolic content of final juice [79]. 
In order to avoid oxidative damage of the probiotics and reduce their sensitivities to reactive oxygen species in fruit and vegetable juices, the modification of the product environment was suggested by the literature data. This modification deals to control the composition of the atmosphere by raising the $\mathrm{CO}_{2}$ content in the headspace [12].

Low-dose irradiation ( $\leq 3 \mathrm{kGy}$ ) used for treatment of juices widely extended their shelf life. Compared to non-irradiated samples, $\gamma$-irradiation $(2.0 \mathrm{kGy})$ provided antioxidants content in grape juice blends and maintained the quality of products. This mild irradiation reduced fungi and yeasts during storage at room temperature of juice blends [80].

\subsubsection{Pre-Treatments Combined with Fermentation}

A comparison of heating and high hydrostatic pressure (HHP) treatment on litchi juice was conducted to ensure the microbial safety of this substrate before its fermentation by L. casei [78] (Table 1). The results showed a good ability of HHP to preserve color, flavor acceptance and antioxidant activity of fermented litchi juice. Authors suggested that HHP and heating process exhibited the potentiality to improve the viability probiotic cells and extend these quality attributes after the storage of 4 weeks at $4{ }^{\circ} \mathrm{C}$.

The work of Mestry et al. [81] focused on the study of formulation and spray drying of a non-dairy fermented beverage. The mixture of watermelon-carrot juice $70: 30$ was fermented at $37^{\circ} \mathrm{C}$ with L. acidophilus. It was found that high temperature of air coupled with longer exposure time at lower feed flowing have a negative impact by reducing viability of probiotic cells, lycopene and $\beta$-carotene contents of juice powder. The increase in atomization pressure enhanced the cohesiveness but decreased flowability of the dried powder because the particle size was lowered. Chen el al. [61] were interested in the study of the effect of HHP treatment on the quality of fruit juice and of the co-fermentation of Lactobacillus rhamnosus and Gluconacetobacter xylinus on the physicochemical properties of yacon-litchi-longan juice. Authors reported that by comparison to thermal processing, the HHP treatment prior to co-fermentation can be used to improve the quality of yacon-litchi-longan juice, especially the flavor and aroma.

The ultrasonic processing was used on pineapple juice as an alternative treatment for the incorporation of probiotics L. casei [59]. According to the authors, sonicated pineapple juice was shown to be a suitable substrate for L. casei cultivation and for the development of an alternative non-dairy probiotic beverage.

Light is widely used in photobioreactors because some microorganisms need light for growth and metabolites production. Fermentation of blueberry fruit powder by Bacillus amyloliquefaciens and $L$. brevis under different light sources illumination (sunlight, LED lights, darkness) showed that fermented extracts have significant antibacterial and antioxidant activities [58].

Among other technological methods to prevent clouding of juices before its lactic fermentation is clarification by using membranes filtration (microfiltration, ultrafiltration ... ) or clarifying agents (gelatin, bentonite ... ). Clarification of pomegranate juice, which has a high content of biological active compounds, reduced the phenolic content and the associated antioxidant activity [57].

\subsection{Microbiota of Traditional and Recently Developed Lactic Acid Fermented Beverages}

The lactic acid fermentation process was used for centuries but still fermentations using plant materials as main substrates are underexplored compared to dairy-based food fermentations, except for a few notable examples which have been subjected to investigation on microbiota.

In water kefir commercial grains, Z. mobilis was shown to be the dominating bacteria, representing up to $87 \%$ of bacteria [13]. LAB identified in water kefir grains are Leuconostoc citreum, L. mesenteroides, L. brevis, Lactobacillus buchneri, L. casei subsp. casei, L. casei subsp. rhamnosus, Lactobacillus diolivorans, Lactobacillus fermentum, Lactobacillus harbinensis, Lactobacillus hilgardii, Lactobacillus hordeii, Lactobacillus kefiranofaciens, Lactobacillus kefiri, Lactobacillus lactis, Lactobacillus mali, Lactobacillus nagelli, Lactobacillus paracasei, Lactobacillus parafarraginis, Lactobacillus perolens, L. plantarum, and Lactobacillus 
satsumensis [24,82]. In commercial grains analyzed by metabarcoding, Lactobacillus accounted for $12-25.4 \%$ of bacteria, whereas Leuconostoc represented $0.4 \%$ to $25.6 \%$. These genera represented between 6.0 and $8.5 \log \mathrm{CFU} / \mathrm{mL}$, whereas yeasts and molds accounted for 5.6 to $7.3 \log \mathrm{CFU} / \mathrm{mL}$ and acetic acid bacteria for 6.0 to $8.3 \log$ CFU/mL [22]. From isolation of 453 bacteria from three water kefir from different origins [83,84] showed the most abundant species were L. hordei and L. nagelii, representing ca. two third of bacteria, the last third being L. citreum or L. mesenteroides. The presence of Bifidobacteria at low levels has been reported [13,84]. Interestingly, the microbial composition of fermentates diverged from water kefir grains, showing an adaptation of the cultures to the medium and environment [13]. Interactions between microorganisms, especially regarding nitrogen sources, has a key role to explain the balance between microflora [82,85].

In Kombucha, the most frequently encountered species are L. kefiranofaciens subsp. kefirgranu. Bifidobacteria and Weissella [25]. Pediococcus pentosaceus [86] has also been identified in Kombucha.

Turkish Shalgam microbiota is mainly composed of yeasts and Lactobacillus (89.63\%), Leuconostoc (9.63\%) and Pediococcus (0.74\%). More specifically, L. plantarum and L. paracasei subsp. paracasei are the most frequent species, followed by L. brevis and L. fermentum. At the beginning of fermentation, $L$. mesenteroides subsp. mesenteroides, P. pentosaceaceus, L. buchneri, Lactobacillus pentosus and L. delbrueckii subsp. delbrueckii were present $[87,88]$. Hardaliye LAB composition comprises L. paracasei subsp. paracasei and L. casei subsp. pseudoplantarum, Lactobacillus pontis, L. brevis, Lactobacillus acetotolerans, Lactobacillus sanfranciscensis, and Lactobacillus vaccinostercus [18].

Sauerkraut fermentation is driven by L. mesenteroides, L. brevis, P. pentosaceus, and L. plantarum [44,89]. However, large scale isolate analyses have revealed new species and succession of species during the process [90]. Heterolactic species, L. mesenteroides, Weissella spp. and L. citreum, dominated the beginning of fermentation. Thereafter, Lactobacillus curvatus, then L. plantarum became dominant [90]. In fermented carrot juice, Leuconostoc, with species L. mesenteroides and Leuconostoc pseudomesenteroides which tolerates better low $\mathrm{pH}$, was present at all stages of fermentation, in a range $0.3 \%$ to $24.6 \%$ depending on sample origin [91]. Lactobacillus was the dominant genus, and its relative abundance reaches $72 \%$ after 30 days of fermentation. The Lactobacillus phylogenetic groups detected in the fermented carrot juices comprised L. brevis, L. casei, Lactobacillus coryniformis, L. plantarum, L. sakei, a subpart of the Lactobacillus salivarius group, and L. vaccinostercus. Lactococcus and Weissella were found in ca. two third of samples, but with abundances up to $50 \%$ and $40 \%$ respectively [91].

The recent investigations for the development of lactic acid fermented fruit or vegetable juices particularly focused on LAB growth and effect on health-related properties (Table 2). Different substrates, water kefir, vegetable or fruit juices, treated in most studies to inactivate indigenous flora prior to fermentation, were used. To perform fermentation, the range of bacterial species is more restrictive than the ones which are found in spontaneous fermentation. The main LAB species belong to Leuconostoc, Lactobacillus, Weissella, Enterococcus and Pediococcus genera. They were isolated from raw or spontaneously fermented vegetables and fruit (Table S1). The most frequent species is L. plantarum. 
Table 2. Lactic fermented fruit or vegetable juices recently developed.

\begin{tabular}{|c|c|c|c|c|}
\hline Raw Material & Pre-Fermentative Treatment & Microorganism & Nutritional Impact & Reference \\
\hline \multicolumn{5}{|l|}{ Water kefir beverages } \\
\hline Cocoa pulp & - & Kefir grains & - & [92] \\
\hline $\begin{array}{l}\text { Kiwifruit, quince, pomegranate, grape, apple, } \\
\text { cactus pear }\end{array}$ & Heat treatment $75^{\circ} \mathrm{C} 5 \mathrm{~min}$ & Kefir grains & Decrease in DPPH ${ }^{1}$ activity & [93] \\
\hline Carrot, fennel, melon, onion, tomato, strawberry & Heat treatment $75^{\circ} \mathrm{C} 5 \mathrm{~min}$ & Kefir grains & - & [56] \\
\hline \multicolumn{5}{|l|}{ Vegetable-based beverages } \\
\hline Tomato juice & Pasteurization (commercial) & $\begin{array}{l}\text { L. acidophilus, L. casei, L. delbrueckii, } \\
\text { L. plantarum }\end{array}$ & - & [39] \\
\hline Tomato juice & $\begin{array}{l}\text { Sucrose addition, Heat treatment } \\
80^{\circ} \mathrm{C} 5 \mathrm{~min}\end{array}$ & $\begin{array}{l}\text { L. plantarum, W. cibaria/confusa, } L \text {. } \\
\text { brevis, P. pentosaceus, Lactobacillus } \\
\text { sp., Enterococcus faecium/faecalis }\end{array}$ & $\begin{array}{l}\text { Lower decrease in ascorbic acid content, glutathione } \\
\text { content and total antioxidant activity in juices started with } \\
\text { L. plantarum compared to other conditions }\end{array}$ & [28] \\
\hline \multicolumn{5}{|l|}{ Red beetroot juice } \\
\hline & Heat treatment $121^{\circ} \mathrm{C} 15 \mathrm{~min}$ & $\begin{array}{l}\text { L. acidophilus, L. casei, L. delbrueckii, } \\
\text { L. plantarum }\end{array}$ & - & [37] \\
\hline Cabbage juice & Heat treatment $121^{\circ} \mathrm{C} 15 \mathrm{~min}$ & L. plantarum, L. casei, L. delbrueckii & - & [38] \\
\hline Celery and beetroot juice & Heat treatment $120^{\circ} \mathrm{C} 15 \mathrm{~min}$ & Bifidobacterium animalis subsp. lactis & - & [94] \\
\hline Carrot & Heat treatment $80^{\circ} \mathrm{C} 20 \mathrm{~min}$ & B. lactis, B. bifidum & Decrease of $10-20 \%$ of $\beta$-carotene and $5-25 \%$ of $\alpha$-carotene & [95] \\
\hline Bitter gourd, bottle gourd, carrot & Heat treatment $80^{\circ} \mathrm{C} 20 \mathrm{~min}$ & L. plantarum & - & [96] \\
\hline \multicolumn{5}{|l|}{ Fruit-based juices } \\
\hline Pineapple & $\begin{array}{l}\text { Filtration } 0.22 \mu \mathrm{m} \text {, heat treatment } \\
75^{\circ} \mathrm{C} 15 \mathrm{~s}\end{array}$ & L. plantarum, L. rossiae & $\begin{array}{l}\text { Slight increase in antioxidant DPPH activity for started } \\
\text { juices }\end{array}$ & [97] \\
\hline Pineapple & Sonication & L. casei & - & [59] \\
\hline Pineapple, papaya, mango, green tea, black tea & $\begin{array}{l}\text { Commercial pasteurized pineapple } \\
\text { juice; } 75^{\circ} \mathrm{C} 5 \mathrm{~min} \text { for papaya and } \\
\text { mango; infusion } 5 \mathrm{~min} \text { in boiling } \\
\text { water for tea }\end{array}$ & $\begin{array}{l}\text { W. cibaria, W. confusa, } W . \\
\text { paramesenteroides, W. soli, } L \text {. } \\
\text { mesenteroides, } L \text {. pseudomesenteroides, } \\
\text { L. citreum, Leuconostoc lactis, } L \text {. } \\
\text { paraplantarum, L. plantarum }\end{array}$ & $\begin{array}{l}\text { Increase in total phenolic content and DPPH activity with } \\
\text { several strains on papaya and pineapple }\end{array}$ & [5] \\
\hline
\end{tabular}


Table 2. Cont.

\begin{tabular}{|c|c|c|c|c|}
\hline Raw Material & Pre-Fermentative Treatment & Microorganism & Nutritional Impact & Reference \\
\hline Pomegranate & Heat treatment $80^{\circ} \mathrm{C} 5 \mathrm{~min}$ & $\begin{array}{l}\text { L. plantarum, L. acidophilus, } L . \\
\text { paracasei, L. delbrueckii }\end{array}$ & $\begin{array}{l}\text { Increase in DPPH radical scavenging activity; decrease in } \\
\text { anthocyanin content; increase in antioxidant activity more } \\
\text { marked with L. acidophilus than with L. plantarum }\end{array}$ & {$[98,99]$} \\
\hline Pomegranate & Filtration $0.22 \mu \mathrm{m}$ & L. plantarum & $\begin{array}{l}\text { Total phenolic compounds concentration and free radical } \\
\text { scavenging activity were better maintained in fermented } \\
\text { juice than in control; fermented juice modulated the } \\
\text { synthesis of the immune mediators into peripheral blood } \\
\text { mononuclear cells }\end{array}$ & [100] \\
\hline Pomegranate & - & $\begin{array}{l}\text { L. acidophilus, L. plantarum, B. } \\
\text { longum subsp. infantis, B. bifidum }\end{array}$ & $\begin{array}{l}\text { Identification of catechin and } \alpha \text {-punicalagin in fermented } \\
\text { juices; increase in antioxidant activity and concentration } \\
\text { of phenolic derivatives during simulated gastrointestinal } \\
\text { digestion of fermented juices; fermentation increased } \\
\text { bioaccessibility of phenolic compounds }\end{array}$ & [101] \\
\hline Pomegranate & Heat treatment $70^{\circ} \mathrm{C} 5 \mathrm{~min}$ & $\begin{array}{l}\text { L. plantarum, L. acidophilus, } L \text {. } \\
\text { delbrueckii }\end{array}$ & $\begin{array}{l}\text { Higher antioxidant activity and total phenolic compounds } \\
\text { in juices fermented with L. plantarum compared to } \\
\text { unfermented }\end{array}$ & [102] \\
\hline Noni & Heat treatment $121^{\circ} \mathrm{C} 15 \mathrm{~min}$ & $\begin{array}{l}\text { L. casei subsp. casei, B. longum, } L \text {. } \\
\text { plantarum }\end{array}$ & $\begin{array}{l}\text { Antioxidant activity of juice fermented with } B \text {. longum } \\
\text { was better maintained than with other strains and } \\
\text { remained similar to initial non fermented juice }\end{array}$ & [103] \\
\hline $\begin{array}{l}\text { Cherries, tomato, blackberry, prune, white grape } \\
\text { juice and aloe vera } \\
\text { Kiwifruit, fennels, spinach, papaya, white grape } \\
\text { juice and aloe vera }\end{array}$ & Heat treatment $80^{\circ} \mathrm{C} 10 \mathrm{~min}$ & $\begin{array}{l}\text { L. plantarum, L. pentosus, } \\
\text { Lactobacillus sp. }\end{array}$ & $\begin{array}{l}\text { Better maintain of radical scavenging activity and total } \\
\text { phenolic compound concentration in started juices }\end{array}$ & [104] \\
\hline Pear & - & L. acidophilus & $\begin{array}{l}\text { Significant increase in } \alpha \text {-glucosidase inhibition for most } \\
\text { samples of fermented juice }\end{array}$ & [105] \\
\hline Cherry juice and broccoli purée & $\begin{array}{l}\text { Cherry juice was heat treated at } \\
121^{\circ} \mathrm{C} \text { for } 10 \mathrm{~min}\end{array}$ & L. plantarum & $\begin{array}{l}\text { Fermented cherry juice and broccoli puree were enriched } \\
\text { in phenolic derivative with high human bioavailability } \\
\text { and biological activity }\end{array}$ & [31] \\
\hline Coconut water & - & L. plantarum, B. animalis subsp. lactis & - & [106] \\
\hline Apple, grape or orange juices & Heat treatment $80^{\circ} \mathrm{C} 20 \mathrm{~min}$ & $\begin{array}{l}\text { L. acidophilus, L. casei, L. rhamnosus, } \\
\text { L. paracasei }\end{array}$ & - & [14] \\
\hline Mango & $\begin{array}{l}\text { Addition of } 50 \mathrm{mg} / \mathrm{L} \text { potassium } \\
\text { metabisulfite and pectinolytic } \\
\text { enzymes, pasteurization }\end{array}$ & $\begin{array}{l}\text { L. acidophilus, L. delbrueckii, } L . \\
\text { plantarum, L. casei }\end{array}$ & - & [107] \\
\hline
\end{tabular}


Table 2. Cont.

\begin{tabular}{|c|c|c|c|c|}
\hline Raw Material & Pre-Fermentative Treatment & Microorganism & Nutritional Impact & Reference \\
\hline Cactus pear & Heat treatment $70^{\circ} \mathrm{C} 5 \mathrm{~min}$ & L. mesenteroides & $\begin{array}{l}\text { Increase in free radical scavenging activity; started } \\
\text { fermented juice markedly inhibited the inflammatory } \\
\text { status of Caco-2/TC7 cells; started fermented juice } \\
\text { scavenged the reactive oxygen species generated by } \mathrm{H} 2 \mathrm{O} 2 \\
\text { on Caco-2 cells; fermented juices variously affected the } \\
\text { immunomodulatory activity towards anti- and } \\
\text { pro-inflammatory cytokines }\end{array}$ & [108] \\
\hline Cactus pear & Dilution 2:1 in water & L. fermentum & $\begin{array}{l}\text { No change in total phenolic content during fermentation; } \\
\text { decrease in antioxidant activity during fermentation }\end{array}$ & [109] \\
\hline Cactus pear & Heat treatment $64^{\circ} \mathrm{C} 30 \mathrm{~min}$ & L. plantarum & $\begin{array}{l}\text { Maintain of health-promoting properties in fermented } \\
\text { cactus pear juice; fermented juice markedly promoted } \\
\text { antioxidant mechanisms in yeast cells; significant decrease } \\
\text { in the body weight gain and amelioration of the insulin } \\
\text { resistance, hyperglycemia, and hyperlipemia after feeding } \\
\text { obese mice with fermented juice }\end{array}$ & [110] \\
\hline Carambola, guava, mango, pitaya & Heat treatment $80^{\circ} \mathrm{C} 5 \mathrm{~min}$ & L. casei, S. thermophilus, L. bulgaricus & - & [16] \\
\hline Sweet lemon juice & Heat treatment $80^{\circ} \mathrm{C} 5 \mathrm{~min}$ & L. plantarum & $\begin{array}{l}\text { No effect of fermented juice on ascorbic acid; decrease in } \\
\text { total phenolic compound concentration; higher } \\
\text { antioxidant activity (DPPH and FRAP }{ }^{2} \text { ) in fermented } \\
\text { juice during } 28 \text { days of storage compared to unfermented } \\
\text { juice }\end{array}$ & [111] \\
\hline Cashew apple juice & Heat treatment $70^{\circ} \mathrm{C} 15 \mathrm{~min}$ & L. plantarum, L. casei, L. acidophilus & $\begin{array}{l}\text { Decrease in hydrolysable tannin content during } \\
\text { fermentation; juice fermented with } L \text {. plantarum retained } \\
\text { better free radical scavenging activity (DPPH and ABTS }{ }^{3} \text { ) } \\
\text { than with other strains }\end{array}$ & [112] \\
\hline Sohiong juice & Heat treatment $70^{\circ} \mathrm{C} 5 \mathrm{~min}$ & L. acidophilus, L. plantarum & - & [113] \\
\hline $\begin{array}{l}\text { Apple, carrot, tomato, cucumber, haw } \\
(40: 25: 15: 15: 5)\end{array}$ & Heat treatment $80^{\circ} \mathrm{C} 20 \mathrm{~min}$ & $\begin{array}{l}\text { L. plantarum, L. casei, L. acidophilus, } \\
\text { L. fermentum, L. rhamnosus }\end{array}$ & - & [114] \\
\hline
\end{tabular}

${ }^{1}$ : DPPH (1,1-diphenyl-2-picrylhydrazyl), ${ }^{2}$ : FRAP Ferric ion Reducing Antioxidant Power, ${ }^{3}$ : ABTS [2,2' -azinobis(3-ethylbenzothiazoline-6-sulphonic acid)]. 
Eventually, strains commercially used for fermentation of juices are mainly from the species $L$. plantarum, Lactobacillus bavaricus, Lactobacillus xylosus, Lactobacillus bifidus and L. brevis. These LAB earned the "generally regarded as safe" (GRAS) status and are therefore considered safe for human consumption [4].

\subsection{Directing Fermentation}

Controlled lactic acid fermentation of fruit and vegetables appeared as a way to develop functional food with standardized and reproducible quality using characterized bacterial strains. This can be achieved using autochthonous, isolated from and re-used on the same raw matrix, or allochthonous, isolated from certain raw matrices but used to ferment various products, starters (Table 3) [10].

Table 3. Properties of autochthonous and allochthonous strains.

\begin{tabular}{cc}
\hline Autochthonous Strains & Allochthonous Strains \\
\hline Highest viscosity of the juice [10] & \\
Highest values of ascorbic acid, glutathione and total & \\
antioxidant activity during storage [10] & Longer latency phases of growth and acidification [10] \\
Rapid decrease in pH [28] & \\
Marked consumption of fermentable carbohydrates [28] & \\
Inhibition of Enterobacteriaceae and yeasts [28] & \\
Positively affected firmness and color [28] & \\
\hline
\end{tabular}

A study done by Di Cagno et al. [28] compared autochthonous L. plantarum starters to allochthonous strains isolated from green olives during fermentation of tomato juice. The results showed that allochthonous strains presented longer latency phases of growth and acidification and that autochthonous strains conferred the highest viscosity to the juice. Indeed, after fermentation at $25^{\circ} \mathrm{C}$ for $17 \mathrm{~h}$ autochthonous strains grew from approximatively 7.0 to $9.6 \log \mathrm{CFU} / \mathrm{mL}$ and allochthonous strains reached approximatively $8.5 \log \mathrm{CFU} / \mathrm{mL}$. Compared to spontaneously fermented pineapple juice, started juice using autochthonous L. plantarum and Lactobacillus rossiae had up to $10^{6}$-fold more LAB, a lower number of yeasts, better preservation of the natural colors, and better overall acceptability [10]. Moreover, juices fermented with autochthonous strains maintained the highest values of ascorbic acid, glutathione and total antioxidant activity during storage [10]. In another study, peeled and cut carrots, French beans and marrows fermented with autochthonous starters isolated from these matrices, namely L. plantarum, L. mesenteroides and P. pentosaceus showed a rapid decrease in $\mathrm{pH}$, marked consumption of fermentable carbohydrates, and inhibition of Enterobacteriaceae and yeasts. These results were not obtained using allochthonous starters belonging to the same species. There are also differences between autochthonous and allochthonous strains regarding the concentration of vitamin C, color indexes, firmness and sensory properties. Indeed, autochthonous strains dominated the microbiota and positively affected firmness and color [10]. Moreover, matrices fermented with the autochthonous starter had significantly higher total concentration of vitamin C compared to those fermented with the allochthonous starter [115].

These few examples demonstrate the advantages of the selection of autochthonous LAB to perform lactic acid fermentation.

\subsection{Nutritional Changes and Functional Effects Mediated by LAB Activity}

Originally devised as a means of food preservation, lactic acid fermentation, by using active microorganisms induces changes in the product physicochemical composition. The liquid phase fermentation occurring in beverages leads to rapid bioconversion, together with the direct release of the metabolites into the culture medium by comparison with solid-state fermentations [116]. The LAB strains selected for fermentation possesses functional properties such as degradation of toxic and anti-nutritional compounds, generation of bioactive molecules, enhancement of the bioavailability of nutritive compounds and may be considered as probiotics [33]. 
Lactic acid is recognized as the main metabolite of $\mathrm{LAB}$ and acidification is one of the desirable effects of their growth. As a consequence, the $\mathrm{pH}$ dropped along the time due to the increase in lactic acid content in fermented beverages. It is observed that the stoichiometric ratio between glucose, fructose and malic acid consumed, and lactic acid and acetic acid synthesized was almost respected in fermented pomegranate juice by L. plantarum [100,117]. The LAB metabolism of carbohydrates varies however from strain to strain and depends on the substrate and even on the fermentation time (Table S2). Fructose appeared to be the most consumed sugar during fermentation of Brazilian cuapussu by L. casei $(84.8 \%)$, followed by sucrose $(62.1 \%)$ and glucose $(34.5 \%)$ [118]. Glucose and sucrose were the main carbon and energy sources for Bifidobacterium growth in carrot juice [95] and for Lactobacillus in pomegranate juice [98].

A study comparing Lactobacillus strains in apple, orange, and grape juices showed that either L. paracasei or L. plantarum were able to decrease glucose, malic, tartatric and citric acids when these acids are available while they were able to increase lactic and succinic acids [119]. L. casei was reported to use quinic acid for compound synthesis and reductions in citric acid levels were reported during the fermentation of pomegranate juice, while L. plantarum might be able to metabolize this acid from catechol $[98,119]$. During elderberry juices fermentation, both malic and citric acids were extensively metabolized by different Lactobacillus spp. while glucose and fructose were almost unaffected suggesting a switch in the microbial metabolism with the use of organic acids instead of sugars in an environment considered as hostile [120]. Combination with treatment by pectinolytic enzymes on wild berries, used in industry for increasing yield and clarify the juice, let to apparent contradictory effects [121]. Where chokeberry fermentation with different $L$. plantarum strains lead to significant reduction of total sugars concentrations and decreased sugar/acid ratio, the same protocol for sea buckthorns led to an increase in $\mathrm{pH}$ and sugar/acid ratio. It seems due to a higher content (or lower reduction) of quinic acid and to the presence of galacturonic acid derived from pectin degradation during enzymatic incubation.

Besides the production of organic acids, LAB also have the ability to contribute to the production of several important bioactive compounds through fermentation. Fruit and vegetable juices are valuable sources of in vitamins, minerals and antioxidant molecules providing a suitable growth substrate for LAB in parallel with a strong health appeal. Beverages fermentation with various strains of LAB has been largely reported to increase the antioxidant activity $[100,111,117,118,122-125]$ sometimes together with an increase in total phenols and flavonoids content $[120,126]$ (Table 2). This is the case for many and varied matrices: pomegranate, blueberry, mulberry, cupuassu (Theobroma grandiflorum), elderberry, Momordica charantia L. and to date, only prickly pear beverages among all lactic fermented beverages was not linked to an increased antioxidant activity by comparison with non-fermented preparation [109]. It is suggested that modification in juice polyphenol profile could be linked to this increase in radical scavenging activity (Table 4). This is in line with data relatives to mulberry juice [124]. A total of 11 phenolic acids, three anthocyanins and five flavonoids were identified in mulberry and it was observed that the concentration of all the phenolic compounds quantified in the fermented sample increased after fermentation either by L. paracasei, L. plantarum or L. acidophilus. The correlation analysis additionally demonstrated that flavonols and anthocyanins were mostly responsible for the increased in ABTS assay (2,2-azinobis (3-ethyl-benzothiazoline-6-sulfonic acid) scavenging activity while phenolic acids and flavonols were responsible for DPPH assay 2,2-diphenyl-1-picrylhydrazyl) scavenging activity and reducing power capacity of the fermented juice. The conversion of complex phenolics into free forms, decarboxylation and depolymerization of high molecular weight phenolic compounds by LAB enzyme are also observed in Momordica charantia L. or cherry juices, leading to the conversion of dihydrocaffeic acid from caffeic acid or catechol from protocatechuic acid by different Lactobacillus subspecies, and the release of numerous flavonols, anthocyanins and phenolics acids according to the initial matrix $[123,124,127]$. Lactobacillus spp. used for cherry juice and broccoli puree fermentation exhibited strain-specific metabolism of phenolic acids, including the release of different hydroxybenzoic acids, hydroxycinnamic acids, and hydroxycinnamic acid derivatives. In this case, $L$. 
plantarum also exhibited the most extensive conversion of protocatechuic, caffeic and p-coumaric acids. L. reuteri did not affect the profile of phenolic acids as it was the only strain capable of hydrolysing chlorogenic acid [119]. Some of the released compounds during fermentation, such as dihydrocaffeic acid or pyrogallol, are strong antioxidants and can explain the enhanced antioxidative properties observed in fermented juices. Furthermore, the stability of polyphenols is $\mathrm{pH}$-dependent. Hence, the decrease in $\mathrm{pH}$ due to lactic acid released might stabilize the phenolic compounds of the fermented beverages [124].

Table 4. Review of the recent studies on changes in polyphenol profile with fermentation of fruit and vegetables by LAB.

\begin{tabular}{|c|c|c|c|c|}
\hline Juices & Compounds Metabolized & Compounds Released & LAB Species & Ref. \\
\hline Apple & $\begin{array}{l}\text { QA, Q, Q-3-gal, Q-3-glc, } \\
\text { phlorizin }\end{array}$ & $\begin{array}{l}\text { 5-O-caffeoylquinic acid, quercetin, } \\
\text { phloretin }\end{array}$ & L. plantarum & [125] \\
\hline \multirow{2}{*}{ Broccoli } & CGA, QA & PA, sinapic acid & L. reuteri & [31] \\
\hline & Sinapic acid & PA & $\begin{array}{l}\text { L. plantarum or } L . \\
\text { mesenteroides }\end{array}$ & [128] \\
\hline Black chokeberry & $\begin{array}{l}\text { CA, CGA, neochlorogenic } \\
\text { acid }\end{array}$ & Anthocyanins: C-3-gal, C-3-glc, C-3-xyl & L. plantarum & [121] \\
\hline Cherry & PTA, CA & catechol, DCA & Lactobacillus spp. & [31] \\
\hline Elderberry & PTA, CA & $\begin{array}{l}\text { DCA, catechol, flavonols glycosides } \\
\text { (Q-3-rut, Q-3-glc) and anthocyanins } \\
\text { (C-3-samb, C-3-glc) }\end{array}$ & $\begin{array}{l}\text { L. plantarum, } L \text {. } \\
\text { rhamnosus and L. casei }\end{array}$ & [129] \\
\hline $\begin{array}{l}\text { Momordica } \\
\text { charantia L. }\end{array}$ & $\begin{array}{l}\text { CA, p-CA, p-HBA, } \\
\text { vinylphenol, catechol, PTA, } \\
\text { BA, vanillin }\end{array}$ & $\begin{array}{l}\text { DCA, phloretic acid, vinylcatechol, } \\
\text { pyrogallol }\end{array}$ & L. plantarum & [123] \\
\hline Mulberry & & $\begin{array}{l}\text { Flavonols (catechin, rutin, morin, } \\
\text { quercetin, kaempferol) } \\
\text { Anthocyanins (C-3-glc, C-3-O-rut, esculin) } \\
\text { Phenolic acids (gallic acid, syringic acid, } \\
\text { vanillic acid, quinic acid, ferulic acid, } \\
\text { cinnamic acid, PTA, CGA, CA, p-HBA, } \\
\text { p-CA) }\end{array}$ & $\begin{array}{l}\text { L. plantarum, } L . \\
\text { acidophilus or } L . \\
\text { paracasei }\end{array}$ & [124] \\
\hline Sea buckthorn & Q-3-glc, I-3-glc & PTA & L. plantarum & [121] \\
\hline
\end{tabular}

Abbreviations: CA, caffeic acid; CGA, chlorogenic acid; PTA, protocatechuic acid; QA, quinic acid; PA, phloretic acid; DCA, dihydrocaffeic acid; BA, benzoic acid; p-HBA, p-hydroxybenzoic acid; p-CA, p-coumaric acid; Q, quercetin; I, isorhamnetin, C, Cyanidin; gal, galactoside; glc, glucoside; rut, rutinoside; xyl, xyloside; gal, galactoside; samb, sambubioside.

The refinement of polyphenols by specific microorganisms may participate in the elaboration of fruit and vegetable juices offering optimized nutritional profiles. Polyphenolic compounds are active against reactive oxygen species (ROS) by scavenging unpaired electrons, and numerous studies attempt to show their interest to limit the risk of various chronic diseases associated with oxidative stress $[130,131]$. Some of the released metabolites along lactic fermentation are able to exert biological activities more relevant to human health in respect to their parent phenolic compounds. For instance, dihydrocaffeic acid was reported to be a more potent antioxidant than caffeic acid and can bioaccumulate inside the endothelial cells employing an intracellular antioxidant activity [132,133].

Phenolic compounds are considered as good regulators of carbohydrate metabolism through the inhibition activities of $\alpha$-glucosidase and $\alpha$-amylase due to their chelating, structure altering, and biological function-limiting capacity to the enzymes [134,135]. Further, antioxidant-rich plant foods have shown an ability to inhibit $\alpha$-glucosidase and $\alpha$-amylase, in addition to pepsin and pancreatic lipase [136-138]. The observed potent inhibitory activities limit or delay starch digestion and absorption, and were connected to subsequently reduce postprandial glycemic response in vivo [137]. Therefore, beverages with a refined polyphenol profile would constitute a promising opportunity for the development of functional foods relevant to diabetes management.

The presence of antinutritive compounds in some plant foods such as tannins, saponins, oxalates, phytic acid or phytates can contribute to bitter taste and mainly to a lower nutrient absorption or 
utilization. Lactic acid fermentation is a long-established processing method to reduce toxicity in tubers and cereals, like cassava or sorghum [139-141]. On beverages, a study on Momordica charantia juices fermented with L. plantarum showed a significant decrease in total saponin content compared with fresh juices and that might be correlated with the enzyme activities of L. plantarum (such as $\beta$-glucosidase) which are responsible for hydrolyzing momordicoside to aglycones [123].

Some of the LAB strains are able to produce exopolysaccharide (EPS), which interacts with the water molecules and control the rheological properties and physical stability of foods. The typically branched heteropolysaccharides are synthesized intracellularly by some strains of Lactobacillus, Lactococcus, Streptococcus, and Bifidobacterium spp. The homopolysacharides, including glucans, fructans and galactans, are obtained via the action of an external enzyme of some strains of Lactobacillus, Leuconostoc, Streptococcus and Weissella [142]. An EPS production resulted in an increased viscosity of fermented litchi juice, along with fructose production, reflecting that EPS synthesis [60]. In pureed carrots, the formation of low-branched dextran was correlated with thickness, while the production of $\beta$-glucan was correlated with elasticity perception. Weissella confusa and L. lactis strains (low-branched dextran-producers) produced pureed carrots with a thick texture and a pleasant odor and flavor [143]. It was also reported that EPS are contributors to improved sensorial acceptance for fermented products [144].

Antioxidant properties were reported for EPS produced by strains of L. plantarum, L. lactis subsp. lactis and L. paracasei subsp. paracasei. Some specific EPS also exhibit significant in vitro immunomodulatory properties [145-147] which is of interest for functional beverages development since it was reported that EPS produced by Weissella cibaria and L. plantarum are resistant to the gastro-intestinal tract conditions [148].

\section{Probiotication}

\subsection{Probiotic Characteristics and Health Benefits}

LAB comprise a significant component of the human gut flora and have beneficial roles in the gastrointestinal tract. They may be considered as probiotics, that are living microbial food supplements, which beneficially affect the host by improving the intestinal microbial balance [11]. The Lactobacillus genus bacteria are able to compete with pathogens for adhesion sites, to antagonize pathogens or to modulate the host's immune response, which will improve nutrition, sooth intestinal disorders, improve the immune system, optimize gut ecology and finally promote overall heath [11]. The Bifidobacterium genus are also interesting for fermentation due to their ability to colonize the intestinal tract and control undesirable intestinal bacteria [149]. According to literature data and the suggestions of the Food and Drug Administration (FDA)/World Health Organization (WHO), in order to fulfill health benefits of probiotic beverages, the strains should have the ability to survive at unfavorable conditions at a concentration of at least 6-7 $\log \mathrm{CFU} / \mathrm{mL}$ and also maintain activity in the final product at the end of the shelf life $[150,151]$.

The LAB population in recently developed lactic fermented fruit or vegetable juices was above the limit of 6-7 $\log \mathrm{CFU} / \mathrm{mL}$, required for probiotic products, at the end of fermentation and even after a storage period of fruit and vegetable beverages. The criteria for a LAB to be used as probiotic include the abilities to withstand into a foodstuff at high cell counts, and remain viable throughout the shelf-life of the product; be nonpathogenic and nontoxic; withstand transit through the GI tract; adhere to the intestinal epithelium cell lining and colonize the lumen of the tract; produce antimicrobial substances towards pathogens; stabilize the intestinal microflora and be associated with health benefits [152]. Basic relevant criteria for LAB selection to develop functional fruit and vegetable beverages are resumed in Figure 2. Scientific investigation has supported the important role of probiotics as a part of a healthy diet for human as well as for animals. Some of the beneficial effects of LAB consumption include improving intestinal tract health; enhancing the immune system; synthesizing and enhancing the bioavailability of nutrients; reducing risk of certain cancers and cardiovascular diseases [152-155]. Therefore, LAB use is of interest for functional food development. 


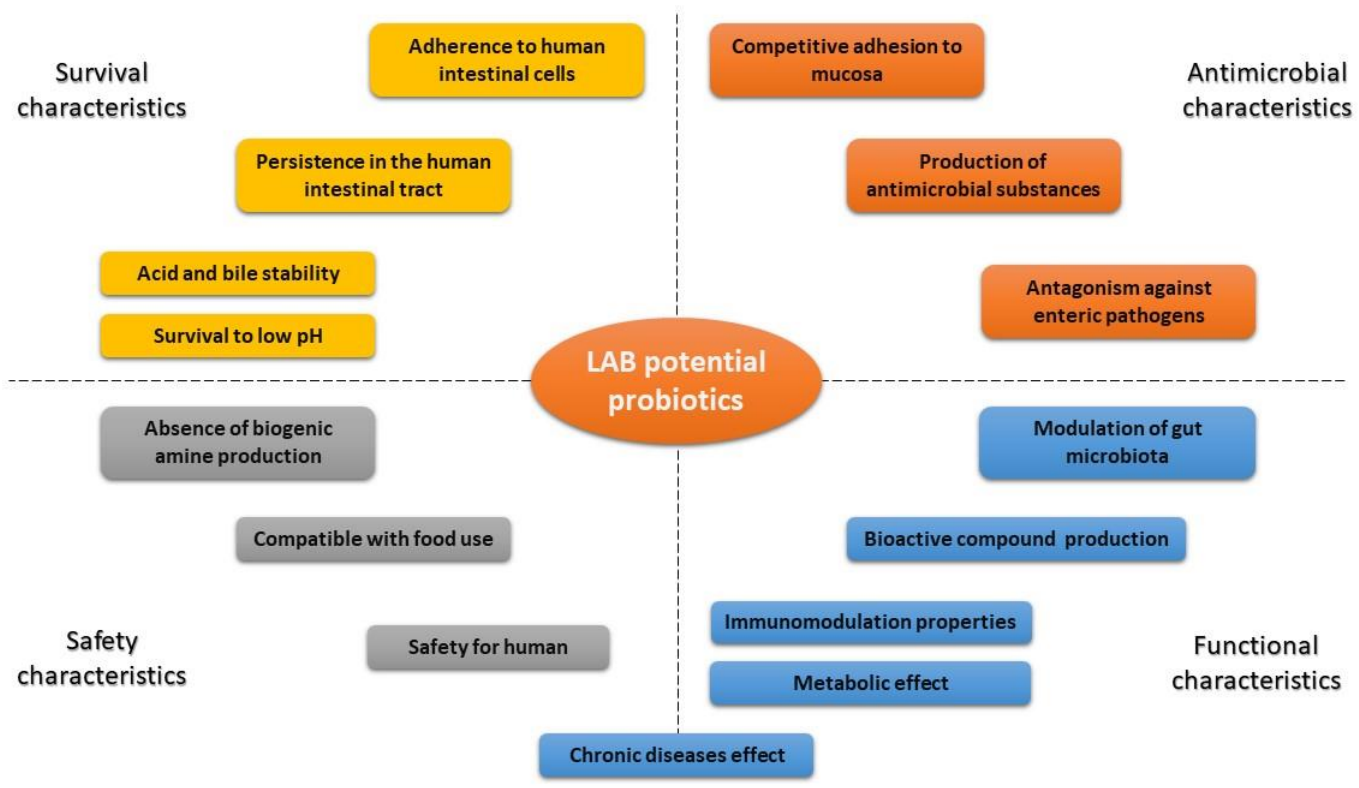

Figure 2. Probiotic strains characteristics of selection for fermented fruit and vegetable beverages.

Only a few studies to date investigated the potential effects of fruit and vegetable juices as carrier for probiotics. In an attempt to increase flavanone bioavailability, orange juices were orally administered to human volunteers together with microencapsulated B. longum within a protein-carbohydrate-oil emulsion. Flavanone bioavailability, however, assessed by 0-24 h urinary excretion, was similar when the juices were consumed with and without acute probiotic intake [156]. Tomato and feijoa juices were compared as fermentable carriers of L. plantarum. The fermented tomato juice showed the largest improvement to intestinal barrier integrity. However, once digested, it did not increase the trans-epithelial electrical resistance on Caco-2 cells, although L. plantarum adhered well to the cells [157]. Blueberry juices mixed with dry probiotic tablets (Bifidobacterium infantis, Bifidobacterium animalis and $L$. acidophilus) were used for supplementation in rats Non-Alcoholic SteatoHepatitis (NASH) models () and significantly reduced metabolic factors, hepatic inflammation and apoptosis connected to NASH progression by affecting the SREBP-1c/PNPLA-3 pathway via PPAR- $\alpha$ [158].

\subsection{Optimized Inoculation to Ensure LAB Viability}

Viability and metabolic activity of the bacteria are important features of probiotic inclusion in beverages. For this purpose, LAB should be first inoculated in adequate amounts to provide benefits to the host and viability should be ensured throughout the shelf life. Different strategies were assessed to optimize living LAB in juices (Table 5). 
Table 5. Process parameters for probiotication of fruit and vegetable juices.

\begin{tabular}{|c|c|c|c|}
\hline Processing Conditions & Raw Material & Mains Findings & Reference \\
\hline $\begin{array}{l}\text { Bleaching }\left(60^{\circ} \mathrm{C} / 20 \mathrm{~min}\right) \text {, extraction, clarification (muslin cloth); } \\
\text { autoclave sterilization }\left(121^{\circ} \mathrm{C} / 15 \mathrm{~min}\right) ; \text { encapsulation of Lactobacillus } \\
\text { spp and S. cerevisiae using alginate coated chitosan beads; cold storage } \\
\text { (6 weeks) }\end{array}$ & Tomato and carrot & $\begin{array}{l}\text { Survivability of encapsulated probiotic cells in a blended juice of } \\
\text { tomato-carrot fruit was improved; overall sensory acceptance (taste } \\
\text { profile, mouthfeel, acidity, flavor, aroma, color) }\end{array}$ & {$[54]$} \\
\hline $\begin{array}{l}\text { Filter sterilization; immobilization of L. acidophilus in an alginate } \mathrm{CaCl}_{2} \\
\text { beads }\end{array}$ & Grapes, orange, watermelon & $\begin{array}{l}\text { Immobilized cultures remained viable over a long period of time; } \\
\text { probiotically drinks were potentially inhibiting the pathogenic growth }\end{array}$ & [159] \\
\hline $\begin{array}{l}\text { Model juice (sucrose, sodium citrate, citric acid powder, distilled } \\
\text { water); water bath pasteurization }\left(85^{\circ} \mathrm{C} / 10 \mathrm{~min}\right) \text {; enrichment by } \\
\text { antioxidants (grape seed and green tea extracts) and vitamins (B, C); } \\
\text { probiotication by (L. rhamnosus, B. lactis, L. paracasei); storage ( } 6 \text { weeks) }\end{array}$ & Model juice & $\begin{array}{l}\text { Turbidity and viscosity of model juice increases } \rightarrow \text { do not support } \\
\text { growth of probiotics; combined effect of probiotics and bioactive } \\
\text { ingredients } \rightarrow \text { improve cells viability on model juice }\end{array}$ & [160] \\
\hline $\begin{array}{l}\text { Sterilized filtration (stainless steel strainer) of juice pulp; } \\
\text { polyphenol-fortified melon juice; inoculation by LAB probiotics and } \\
\text { incubation }\left(4^{\circ} \mathrm{C} / 4 \text { days }\right)\end{array}$ & Melon & $\begin{array}{l}\text { Herbal extract based additive } \rightarrow \text { increases antioxidant activity; } \\
\text { delivering viable LAB }+ \text { survivability and growth into refrigerated } \\
\text { enriched juice }\end{array}$ & [161] \\
\hline $\begin{array}{l}\text { Electrospraying assisted microencapsulation of } L \text {. rhamnosus } \rightarrow \\
\text { Silica-coated alginate beads; freeze drying }\left(85^{\circ} \mathrm{C} ; 0.2 \mathrm{mbar} ; 20 \mathrm{~h}\right) \text { of } \\
\text { microcapsules; addition of these microcarriers to pasteurized apple } \\
\text { juice }\end{array}$ & Apple & $\begin{array}{l}\text { Silica-coated beads diminished the leakage of } L \text {. rhamnosus when } \\
\text { compared to alone alginate beads } \rightarrow \text { More protection and survival }\end{array}$ & [162] \\
\hline $\begin{array}{l}\text { Inoculation L. acidophilus of juice mixture }(70: 30 \mathrm{v} / \mathrm{v}) \text {; air spray drying } \\
\left(\mathrm{T}_{\text {air }}: 120-160^{\circ} \mathrm{C} \text {; flow rate: } 25 \mathrm{~mL} / \mathrm{min}\right) \text {; with maltodextrin }\end{array}$ & Watermelon and carrot & $\begin{array}{l}\text { Higher } \mathrm{T}_{\text {air }}+\text { longer time }+ \text { lower flow } \rightarrow \text { Reducing of cell viability, } \\
\text { lycopene and } \beta \text {-carotene of dried juice (powder); increased } \\
\text { atomization pressure } \rightarrow \text { Better cohesiveness but less flowability of } \\
\text { juice powder }\end{array}$ & [81] \\
\hline $\begin{array}{l}\text { Mixing }(45 \mathrm{~s}) \text {; short pasteurization }\left(95^{\circ} \mathrm{C} / 15 \mathrm{~s}\right) \text {; skin and seeds removal } \\
\text { (mesh screen); juice was kept }\left(88^{\circ} \mathrm{C} / 2 \mathrm{~min}\right) ; \mathrm{L} \text {. acidophilus cell } \\
\text { immobilization k carrageenan beads; free and cell-immobilized } \\
\text { fermentation of tomato juice; cold storage }\left(4^{\circ} \mathrm{C} / 10 \text { weeks }\right)\end{array}$ & Fresh raw tomato & $\begin{array}{l}\text { Fermentation was improved by immobilized cells } \rightarrow \text { protection effect } \\
\text { against adverse environment of tomato juice; immobilization increased } \\
\text { growth and viability of L. acidophilus during fermentation and storage } \\
\text { compared to the free cells; high overall palatability score (before and } \\
\text { during cold storage) of juice }\end{array}$ & [164] \\
\hline
\end{tabular}




\subsubsection{Immobilization}

The encapsulation approach to extend shelf life of lactic acid fermented juices and maintain cell viability of bacterial strains under storage conditions was discussed specially for fruit juice, wherein LAB may show some sensitivity to acidic conditions due to the typically low $\mathrm{pH}$, between $\mathrm{pH} 2.5$ and 3.7. The microencapsulation of $L$. casei with sodium alginate by emulsion system showed difference in viability according to the fruit juice. A $100 \%$ rate of viability in pineapple juice and $91 \%$ in orange juice was found whereas no viability was found at the end of the storage period in raspberry juice, because of the absorption of high concentrations of anthocyanin inside microcapsules [165].

The stability of free and entrapped L. rhamnosus in alginate and silica-coated alginate carriers was compared in apple juice during cold storage [162]. Encapsulation being more efficient for LAB viability with core-shell alginate-silica beads in both the filtrate and inside the carriers.

Pineapple juice was proved to be a suitable carrier for encapsulated probiotic cell viability whereas microcapsules and free cells were not stable in strawberry-apple juice and died after 14 days of storage at $22{ }^{\circ} \mathrm{C}[166]$.

Viability of encapsulated L. casei, L. plantarum and L. fermentum cells was higher than free cells in tomato and carrot juices over a period of cold storage, indicating better cell protection using alginate coated chitosan beads even if the sensory quality and the turbidity of vegetable juices changed [167].

Viable count of encapsulated L. plantarum in grapes, orange, and watermelon juices was evaluated as $7 \log \mathrm{CFU} / \mathrm{mL}$ or more throughout the storage whereas, the viable counts of free cells were remarkably dropped to 2-3 $\log \mathrm{CFU} / \mathrm{mL}$ during the storage [159]. Authors reported that the encapsulation of probiotics in alginate beads can protect the inside cells from oxygen and high concentrations of substrates or products, and unfavorable conditions like low $\mathrm{pH}$, in fruit juices.

Microencapsulation by spray drying using maltodextrin or inulin as encapsulating agents affects the survival rate, as highlighted in passion fruit juice added with B. animalis ssp. lactis. During storage at $25^{\circ} \mathrm{C}$, the maltodextrin encapsulated samples showed lower viability, showing that inulin may offer better protection to the lactic bacteria at this temperature. No difference was detected at $4{ }^{\circ} \mathrm{C}$ [168].

Comparison of beverages containing commercial pectin or pectin extracted from passion fruit pulp as probiotic carrier for L. rhamnosus showed no differences according to the carrier, with $100 \%$ survival rates when the juices were not fermented. In fermented beverage survivals were $73 \%$ for commercial pectin and $60 \%$ when CP and PE for pectin extracted, respectively [169].

Vivek et al. [163] conducted a study to characterize and evaluate the physical stability of spray dried probiotic Sohiong fruit powder during storage. The determination of moisture isotherms at various temperature and relative humidity were made. It was found that spray drying technique played a role to preserve and maintain L. plantarum cells to be viable $\left(10^{6} \mathrm{cells} / \mathrm{g}\right)$ after long period of storage.

The suitability of entrapping L. acidophilus on the k-carrageenan to perform tomato juice fermentation was evaluated [164]. Authors showed that the unfavorable conditions in tomato juice could be overcome and certain benefits on cell viability were provided by LAB immobilization in the fermented juice.

Finally, a study investigated the impact of the probiotic addition methodology on the quality parameters of orange juice [170]. The direct addition of the commercial culture appeared to be the most suitable methodology, resulting in products with physical and chemical characteristics and sensory acceptance similar to those of the puree product, and improved the volatile compounds profile contrary to the addition of the activated probiotic culture or encapsulated probiotic culture.

\subsubsection{Antioxidants}

Damage to cell membranes due to oxidation might occur during long-term storage and antioxidants addition was tested to examine their influence on LAB viability in fruit juices. In a model juice made with sucrose, sodium citrate and citric acid powder, the addition of green tea extract, vitamin $C$, or grape seed extract showed better survival of LAB bacteria (L. rhamnosus, L. paracasei, B. lactis) after 
6 weeks of storage, than the addition of vitamin B2, vitamin B3, vitamin B6 or vitamin E [160]. The effect of melon juice supplementation with phenolic compounds in the form of herbal extract, was also studied on the viability of six probiotic-type LAB [161]. This study highlighted the synergistic interaction between antioxidant compounds of melon juice and herbal phenolic extract to improve the survivability of probiotic LAB under cold storage for 4 days.

\subsubsection{Co-Inoculation}

As yeast also played an important role in the production of many traditional fermented foods and beverages, it was supposed they might positively stimulate the abundance of LAB in fermented environments. This novel technological approach was tested on non-edible Prunus mahaleb allowing to efficiently reduce sourness making $P$. mahaleb beverage suitable for consumption. Co-inoculation by Saccharomyces cerevisiae and L. plantarum resulted in a high cell count of approximately 7-8 $\log$ $\mathrm{CFU} / \mathrm{mL}$ after 4 days of fermentation. However, strains were both slowed down from day 8 to the end of fermentation, contrary to fermentation by L. plantarum alone [171].

Yeast use for co-inoculation seems to be conditioned to strain compatibility, since the addition of Williopsis saturnus did not bring any effect on the survivability nor on substrate transformation by bifidobacteria, leading to early death of the yeast on durian pulp puree. This is in contrast to the enhanced viability of $L$. casei and sugar metabolism (fructose and glucose) as well as the various volatile compounds (alcohols, esters and aldehydes) produced that may improve the aroma profiles of the fermented durian pulp puree [172].

\section{Perspectives Related to LAB Physiological Traits and Metabolism of Phenolic Compounds}

Fruit and vegetable juices contain a large diversity of carotenoids and phenolic compounds. These compounds are involved in antioxidant activity and their bioconversion by LAB has been demonstrated in many fruit and vegetables.

The effect of processing, including lactic acid fermentation, on antioxidant compound composition is a key stone to understanding health-promoting properties of fermented fruit and vegetable beverages $[33,57]$. Antioxidant compounds include carotenoids, flavonoids such as anthocyanins, procyanidins, and phenolic acids, including condensed and hydrolyzable tannins. Many of these compounds are glycosylated and the glycosidic group nature and position influences their absorption and biological activity. The enzymatic machinery of LAB involved in metabolization of these compounds is still poorly characterized [33,157,173-176].

Only recent studies investigated the use of metabolomics to decipher changes in beneficial bioactive compounds resulting from lactic fermentation of fruit and vegetable juices $[101,177,178]$. The development of analytical methods and data analyses may be used to predict the nutritional (and sensory) quality of fermented foods. Interestingly, Tomita et al. (2017) [179] discriminated vegetable (leaves and roots) juices fermented with different Lactobacillus strains on the basis of fermentative metabolites and low-abundance metabolites.

Recent developments into comparative genomics, functional genomics, transcriptomics and metabolomics open new horizon for tailoring LAB strain selection for specific ecological niches or metabolism of phenolic compounds. Reconstruction of fermentative metabolic pathways have been successfully applied for L. mesenteroides [180]. This approach can be implemented together with the collection of transcriptional datasets to increase knowledge on metabolic pathways and identification of specific traits relevant for the adaptation of LAB to the ecological niche, and for phenolic compound metabolism [181]. Functional genomics, transcriptomics and metabolomics would then contribute to exploit the potential of fruit and vegetables for human health.

\section{Conclusions}

Fruit and vegetable juices are suitable substrates for lactic acid fermentation or as vectors for probiotic bacteria. The combination of active LAB with fruit and vegetable properties presents 
numerous nutritional advantages. Moreover, synergistic effects can be expected resulting from LAB metabolism. The advantages of the combination cover lactose-free beverages, specific taste, production of EPS, decrease in sugar content and production of bioactive compounds. LAB consumption can improve intestinal tract health, enhance the immune system, synthesize and enhance the bioavailability of nutrients and reduce the risk of certain cancers and cardiovascular diseases. LAB fermented fruit and vegetable beverages may provide a new asset for metabolic disease management.

Processing of juice, especially with alternative technologies to heat treatment, is not only beneficial as a pre-fermentative microbial decontamination treatment but can affect LAB activity and resulting biochemical modifications. Alternatives to conventional heat treatments and pre-treatments of beverages contribute to preserving nutritional properties, reducing oxidative damages of LAB, increasing functional value and promoting the growth of fermentation microorganisms. Encapsulation or addition of antioxidants has an effective role in maintaining probiotic LAB viability.

Future challenges come from a rational tailored selection of strain-substrate-processing in order to increase the nutritional, sensory and microbiological quality of resulting beverages. To that aim, "omic" approaches open new perspectives.

Supplementary Materials: The following are available online at http://www.mdpi.com/2306-5710/6/1/8/s1. Table S1: Species of lactic acid bacteria, which were isolated from raw or spontaneously fermented vegetables and fruit; Table S2: Review of the recent studies on sugars and organic acids metabolism by LAB along fermentation of plant beverages.

Author Contributions: All authors contributed to writing and editing this review. All authors have read and agreed to the published version of the manuscript.

Funding: This work was partly funded by Federation BioST from University of La Réunion.

Conflicts of Interest: The authors declare no conflict of interest.

\section{References}

1. Tamang, J.P.; Watanabe, K.; Holzapfel, W.H. Review: Diversity of microorganisms in global fermented foods and beverages. Front. Microbiol. 2016, 7, 377. [CrossRef] [PubMed]

2. Charlton, K.; Kowal, P.; Soriano, M.M.; Williams, S.; Banks, E.; Vo, K.; Byles, J. Fruit and vegetable intake and body mass index in a large sample of middle-aged Australian men and women. Nutrients 2014, 6, 2305-2319. [CrossRef] [PubMed]

3. Tamang, J. Plant-based fermented foods and beverages of Asia. In Handbook of Plant-Based Fermented Food and Beverage Technology, 2nd ed.; CRC Press: Boca Raton, FL, USA, 2012; pp. 49-90.

4. Karovičová, J.; Kohajdová, Z. Lactic acid fermented vegetable juices. Hortic. Sci. 2011, 30, 152-158. [CrossRef]

5. Fessard, A.; Kapoor, A.; Patche, J.; Assemat, S.; Hoarau, M.; Bourdon, E.; Bahorun, T.; Remize, F. Lactic fermentation as an efficient tool to enhance the antioxidant activity of tropical fruit juices and teas. Microorganisms 2017, 5, 2. [CrossRef] [PubMed]

6. Mokoena, M.P.; Mutanda, T.; Olaniran, A.O. Perspectives on the probiotic potential of lactic acid bacteria from African traditional fermented foods and beverages. Food Nutr. Res. 2016, 60, 29630. [CrossRef] [PubMed]

7. Legras, J.-L.; Merdinoglu, D.; Cornuet, J.-M.; Karst, F. Bread, beer and wine: Saccharomyces cerevisiae diversity reflects human history. Mol. Ecol. 2007, 16, 2091-2102. [CrossRef]

8. Cavanagh, D.; Fitzgerald, G.F.; McAuliffe, O. From field to fermentation: The origins of Lactococcus lactis and its domestication to the dairy environment. Food Microbiol. 2015, 47, 45-61. [CrossRef]

9. Campbell-Sills, H.; el Khoury, M.; Favier, M.; Romano, A.; Biasioli, F.; Spano, G.; Sherman, D.J.; Bouchez, O.; Coton, E.; Coton, M.; et al. Phylogenomic Analysis of Oenococcus oeni reveals specific domestication of strains to cider and wines. Genome Biol. 2015, E7, 1506-1518. [CrossRef]

10. Azam, M.; Mohsin, M.; Ijaz, H.; Tulain, U.R.; Ashraf, M.A.; Fayyaz, A.; Abadeen, Z.; Kamran, Q. Review-Lactic acid bacteria in traditional fermented Asian foods. Pak. J. Pharm. Sci. 2017, 30, 1803-1814.

11. di Cagno, R.; Coda, R.; de Angelis, M.; Gobbetti, M. Exploitation of vegetables and fruits through lactic acid fermentation. Food Microbiol. 2013, 33, 1-10. [CrossRef]

12. Corbo, M.R.; Bevilacqua, A.; Petruzzi, L.; Casanova, F.P.; Sinigaglia, M. Functional beverages: The emerging side of functional foods. Compr. Rev. Food Sci. Food Saf. 2014, 13, 1192-1206. [CrossRef] 
13. Marsh, A.J.; O'Sullivan, O.; Hill, C.; Ross, R.P.; Cotter, P.D. Sequence-based analysis of the microbial composition of water kefir from multiple sources. FEMS Microbiol. Lett. 2013, 348, 79-85. [CrossRef] [PubMed]

14. Espirito-Santo, A.P.; Carlin, F.; Renard, C.M.G.C. Apple, grape or orange juice: Which one offers the best substrate for lactobacilli growth?-A screening study on bacteria viability, superoxide dismutase activity, folates production and hedonic characteristics. Food Res. Int. 2015, 78, 352-360. [CrossRef] [PubMed]

15. Les Grands Prix SIAL Innovation. Available online: https://www.sialparis.fr/Programme/SIAL-Innovation/Lesgagnants-du-prix-SIAL-Innovation/GRAND-PRIX-OR-Namaste-water-kefirs (accessed on 13 December 2019).

16. Maldonado, R.R.; da Costa Araújo, L.; da Silva Dariva, L.C.; Rebac, K.N.; de Souza Pinto, I.A.; Prado, J.P.R.; Saeki, J.K.; Silva, T.S.; Takematsu, E.K.; Tiene, N.V.; et al. Potential application of four types of tropical fruits in lactic fermentation. LWT 2017, 86, 254-260. [CrossRef]

17. Marsh, A.J.; O'Sullivan, O.; Hill, C.; Ross, R.P.; Cotter, P.D. Sequence-based analysis of the bacterial and fungal compositions of multiple kombucha (tea fungus) samples. Food Microbiol. 2014, 38, 171-178. [CrossRef] [PubMed]

18. Altay, F.; Karbancioglu-Güler, F.; Daskaya-Dikmen, C. A review on traditional Turkish fermented non-alcoholic beverages: Microbiota, fermentation process and quality characteristics. Int. J. Food Microbiol. 2013, 167, 44-56. [CrossRef] [PubMed]

19. de la Fuente-Salcido, N.M.; Castañeda-Ramírez, J.C.; García-Almendárez, B.E.; Bideshi, D.K.; Salcedo-Hernández, R.; Barboza-Corona, J.E. Isolation and characterization of bacteriocinogenic lactic bacteria from M-Tuba and Tepache, two traditional fermented beverages in México. Food Sci. Nutr. 2015, 3, 434-442. [CrossRef]

20. Sõukand, R.; Pieroni, A.; Biró, M.; Dénes, A.; Dogan, Y.; Hajdari, A.; Kallea, R.; Reade, B.; Mustafa, B.; Nedelcheva, A.; et al. An ethnobotanical perspective on traditional fermented plant foods and beverages in Eastern Europe. J. Ethnopharmacol. 2015, 170, 284-296. [CrossRef]

21. Pidoux, M. The microbial flora of sugary kefir grain (the gingerbeer plant): Biosynthesis of the grain from Lactobacillus hilgardii producing a polysaccharide gel. MIRCEN J. Appl. Microbiol. Biotechnol. 1989, 5, 223-238. [CrossRef]

22. Magalhães, K.T.; de M. Pereira, G.V.; Dias, D.R.; Schwan, R.F. Microbial communities and chemical changes during fermentation of sugary Brazilian kefir. World J. Microbiol. Biotechnol. 2010, 26, 1241-1250. [CrossRef]

23. Laureys, D.; de Vuyst, L. Microbial species diversity, community dynamics, and metabolite kinetics of water kefir fermentation. Appl. Environ. Microbiol. 2014, 80, 2564-2572. [CrossRef] [PubMed]

24. da CP Miguel, M.G.; Cardoso, P.G.; Magalhães, K.T.; Schwan, R.F. Profile of microbial communities present in tibico (sugary kefir) grains from different Brazilian States. World J. Microbiol. Biotechnol. 2011, 27, 1875-1884. [CrossRef]

25. Chakravorty, S.; Bhattacharya, S.; Chatzinotas, A.; Chakraborty, W.; Bhattacharya, D.; Gachhui, R. Kombucha tea fermentation: Microbial and biochemical dynamics. Int. J. Food Microbiol. 2016, 220, 63-72. [CrossRef] [PubMed]

26. Baschali, A.; Tsakalidou, E.; Kyriacou, A.; Karavasiloglou, N.; Matalas, A.-L. Traditional low-alcoholic and non-alcoholic fermented beverages consumed in European countries: A neglected food group. Nutr. Res. Rev. 2017, 30, 1-24. [CrossRef] [PubMed]

27. Sireswar, S.; Montet, D.; Dey, G. Principal component analysis for clustering probiotic-fortified beverage matrices efficient in elimination of Shigella sp. Fermentation 2018, 4, 34. [CrossRef]

28. di Cagno, R.; Surico, R.F.; Paradiso, A.; de Angelis, M.; Salmon, J.-C.; Buchin, S.; de Gara, L.; Gobbetti, M. Effect of autochthonous lactic acid bacteria starters on health-promoting and sensory properties of tomato juices. Int. J. Food Microbiol. 2009, 128, 473-483. [CrossRef]

29. di Cagno, R.; Surico, R.F.; Minervini, G.; de Angelis, M.; Rizzello, C.G.; Gobbetti, M. Use of autochthonous starters to ferment red and yellow peppers (Capsicum annum L.) to be stored at room temperature. Int. J. Food Microbiol. 2009, 130, 108-116. [CrossRef]

30. Fessard, A.; Remize, F. Genetic and technological characterization of lactic acid bacteria isolated from tropically grown fruits and vegetables. Int. J. Food Microbiol. 2019, 301, 61-72. [CrossRef]

31. Filannino, P.; Bai, Y.; di Cagno, R.; Gobbetti, M.; Gänzle, M.G. Metabolism of phenolic compounds by Lactobacillus spp. during fermentation of cherry juice and broccoli puree. Food Microbiol. 2015, 46, 272-279. [CrossRef] 
32. Martins, E.M.F.; Ramos, A.M.; Vanzela, E.S.L.; Stringheta, P.C.; de Oliveira Pinto, C.L.; Martins, J.M. Products of vegetable origin: A new alternative for the consumption of probiotic bacteria. Food Res. Int. 2013, 51, 764-770. [CrossRef]

33. Septembre-Malaterre, A.; Remize, F.; Poucheret, P. Fruits and vegetables, as a source of nutritional compounds and phytochemicals: Changes in bioactive compounds during lactic fermentation. Food Res. Int. 2018, 104, 86-99. [CrossRef] [PubMed]

34. Capozzi, V.; Fragasso, M.; Romaniello, R.; Berbegal, C.; Russo, P.; Spano, G. Spontaneous food fermentations and potential risks for human health. Fermentation 2017, 3, 49. [CrossRef]

35. Fessard, A.; Bourdon, E.; Payet, B.; Remize, F. Identification, stress tolerance, and antioxidant activity of lactic acid bacteria isolated from tropically grown fruits and leaves. Can. J. Microbiol. 2016, 62, 550-561. [CrossRef] [PubMed]

36. Buruleanu, L.; Nicolescu, C.L.; Avram, D.; Bratu, M.G.; Manea, I. Survival of probiotic bacteria during lactic acid fermentation of vegetable juices. J. Agroaliment. Process. Technol. 2009, 15, 132-139.

37. Yoon, K.Y.; Woodams, E.E.; Hang, Y.D. Fermentation of beet juice by beneficial lactic acid bacteria. LWT-Food Sci. Technol. 2005, 38, 73-75. [CrossRef]

38. Yoon, K.Y.; Woodams, E.E.; Hang, Y.D. Production of probiotic cabbage juice by lactic acid bacteria. Bioresour. Technol. 2006, 97, 1427-1430. [CrossRef]

39. Yoon, K.Y.; Woodams, E.E.; Hang, Y.D. Probiotication of tomato juice by lactic acid bacteria. J. Microbiol. 2004, 42, 315-318.

40. Swain, M.R.; Anandharaj, M.; Ray, R.C.; Rani, R.P. Fermented fruits and vegetables of Asia: A potential source of probiotics. Biotechnol. Res. Int. 2014, 2014, 250424. [CrossRef]

41. Bergsveinson, J.; Kajala, I.; Ziola, B. Next-generation sequencing approaches for improvement of lactic acid bacteria-fermented plant-based beverages. AIMS Microbiol. 2017, 3, 8-24. [CrossRef]

42. Corcoran, B.M.; Stanton, C.; Fitzgerald, G.F.; Ross, R.P. Survival of probiotic Lactobacilli in acidic environments is enhanced in the presence of metabolizable sugars. Appl. Environ. Microbiol. 2005, 71, 3060-3067. [CrossRef]

43. Kang, M.-S.; Kim, Y.-S.; Lee, H.-C.; Lim, H.-S.; Oh, J.-S. Comparison of temperature and additives affecting the stability of the probiotic Weissella cibaria. Chonnam Med. J. 2012, 48, 159-163. [CrossRef] [PubMed]

44. Beganović, J.; Kos, B.; Pavunc, A.L.; Uroić, K.; Jokić, M.; Šušković, J. Traditionally produced sauerkraut as source of autochthonous functional starter cultures. Microbiol. Res. 2014, 169, 623-632. [CrossRef] [PubMed]

45. Verón, H.E.; di Risio, H.D.; Isla, M.I.; Torres, S. Isolation and selection of potential probiotic lactic acid bacteria from Opuntia ficus-indica fruits that grow in Northwest Argentina. LWT 2017, 84, 231-240. [CrossRef]

46. de Souza, J.V.; Dias, F.S. Protective, technological, and functional properties of select autochthonous lactic acid bacteria from goat dairy products. Curr. Opin. Food Sci. 2017, 13, 1-9. [CrossRef]

47. Fessard, A.; Remize, F. Why are Weissella spp. not used as commercial starter cultures for food fermentation? Fermentation 2017, 3, 38. [CrossRef]

48. Xu, X.; Luo, D.; Bao, Y.; Liao, X.; Wu, J. Characterization of diversity and probiotic efficiency of the autochthonous lactic acid bacteria in the fermentation of selected raw fruit and vegetable juices. Front. Microbiol. 2018, 9, 2539. [CrossRef]

49. Passerini, D.; Beltramo, C.; Coddeville, M.; Quentin, Y.; Ritzenthaler, P.; Daveran-Mingot, M.L.; le Bourgeois, P. Genes but not genomes reveal bacterial domestication of Lactococcus lactis. PLoS ONE 2010, 5, e15306. [CrossRef]

50. Manno, M.T.; Zuljan, F.; Alarcon, S.; Esteban, L.; Blancato, V.; Espariz, M.; Magni, C. Genetic and phenotypic features defining industrial relevant Lactococcus lactis, L. cremoris and L. lactis biovar. diacetylactis strains. J. Biotechnol. 2018, 282, 25-31. [CrossRef]

51. Passerini, D.; Laroute, V.; Coddeville, M.; le Bourgeois, P.; Loubière, P.; Ritzenthaler, P.; Cocaign-Bousquet, M.; Daveran-Mingot, M.-L. New insights into Lactococcus lactis diacetyl- and acetoin-producing strains isolated from diverse origins. Int. J. Food Microbiol. 2013, 160, 329-336. [CrossRef]

52. Endo, A.; Tanizawa, Y.; Tanaka, N.; Maeno, S.; Kumar, H.; Shiwa, Y.; Okada, S.; Yoshikawa, H.; Dicks, L.; Nakagawa, J.; et al. Comparative genomics of Fructobacillus spp. and Leuconostoc spp. reveals niche-specific evolution of Fructobacillus spp. BMC Genom. 2015, 16, 1117. [CrossRef]

53. Martino, M.E.; Bayjanov, J.R.; Caffrey, B.E.; Wels, M.; Joncour, P.; Hughes, S.; Gillet, B.; Kleerebeze, M.; van Hijum, S.A.F.T.; Leulier, F. Nomadic lifestyle of Lactobacillus plantarum revealed by comparative genomics of 54 strains isolated from different habitats. Environ. Microbiol. 2016, 18, 4974-4989. [CrossRef] [PubMed] 
54. Sivudu, S.N.; Umamahesh, K.; Reddy, O.V.S. A comparative study on probiotication of mixed watermelon and tomato juice by using probiotic strains of Lactobacilli. Int. J. Curr. Microbiol. Appl. Sci. 2014, 3, 977-984.

55. Koh, J.-H.; Kim, Y.; Oh, J.-H. Chemical characterization of tomato juice fermented with bifidobacteria. J. Food Sci. 2010, 75, C428-C432. [CrossRef] [PubMed]

56. Corona, O.; Randazzo, W.; Miceli, A.; Guarcello, R.; Francesca, N.; Erten, H.; Moschettia, G.; Settanni, L. Characterization of kefir-like beverages produced from vegetable juices. LWT Food Sci. Technol. 2016, 66, 572-581. [CrossRef]

57. Gumienna, M.; Szwengiel, A.; Górna, B. Bioactive components of pomegranate fruit and their transformation by fermentation processes. Eur. Food Res. Technol. 2016, 242, 631-640. [CrossRef]

58. Jeong, S.-Y.; Velmurugan, P.; Lim, J.-M.; Oh, B.-T.; Jeong, D.-Y. Photobiological (LED light)-mediated fermentation of blueberry (Vaccinium corymbosum L.) fruit with probiotic bacteria to yield bioactive compounds. LWT 2018, 93, 158-166. [CrossRef]

59. Costa, M.G.M.; Fonteles, T.V.; de Jesus, A.L.T.; Rodrigues, S. Sonicated pineapple juice as substrate for $L$. casei cultivation for probiotic beverage development: Process optimisation and product stability. Food Chem. 2013, 139, 261-266. [CrossRef]

60. Zheng, X.; Yu, Y.; Xiao, G.; Xu, Y.; Wu, J.; Tang, D.; Zhang, Y. Comparing product stability of probiotic beverages using litchi juice treated by high hydrostatic pressure and heat as substrates. Innov. Food Sci. Emerg. Technol. 2014, 23, 61-67. [CrossRef]

61. Chen, H.; Xiao, G.; Xu, Y.; Yu, Y.; Wu, J.; Zou, B. High hydrostatic pressure and co-fermentation by Lactobacillus rhamnosus and Gluconacetobacter xylinus improve flavor of yacon-litchi-longan juice. Foods 2019, 8, 8. [CrossRef]

62. Miller, F.A.; Silva, C.L.M. Thermal treatment effects in fruit juices. In Advances in Fruit Processing Technologies; Rodrigues, S., Fernandes, F.A.N., Eds.; CRC Press: Boca Raton, FA, USA, 2012; pp. 363-383. ISBN 978-1-4398-5153-1.

63. Marszałek, K.; Krzyżanowska, J.; Woźniak, Ł.; Skapska, S. Kinetic modelling of polyphenol oxidase, peroxidase, pectin esterase, polygalacturonase, degradation of the main pigments and polyphenols in beetroot juice during high pressure carbon dioxide treatment. LWT-Food Sci. Technol. 2017, 85, 412-417. [CrossRef]

64. Mercali, G.D.; Gurak, P.D.; Schmitz, F.; Marczak, L.D.F. Evaluation of non-thermal effects of electricity on anthocyanin degradation during ohmic heating of jaboticaba (Myrciaria cauliflora) juice. Food Chem. 2015, 171, 200-205. [CrossRef] [PubMed]

65. Profir, A.G.; Vizireanu, C. Effect of the preservation processes on the storage stability of juice made from carrot, celery and beetroot. J. Agroaliment. Process. Technol. 2013, 19, 99-104.

66. Dima, F.; Istrati, D.; Garnai, M.C.; Serea, V.; Vizireanu, C. Study on obtaining vegetables juices with high antioxidant potential, preserved by ohmic pasteurization. J. Agroaliment. Process. Technol. 2015, 21, 67-74.

67. Bhat, S.; Saini, C.S.; Kumar, M.; Sharma, H.K. Effect of thermal and alternate thermal processing on bottle gourd (L agenaria siceraria) juice. J. Food Process. Preserv. 2017, 41, e12911. [CrossRef]

68. Achir, N.; Dhuique-Mayer, C.; Hadjal, T.; Madani, K.; Pain, J.-P.; Dornier, M. Pasteurization of citrus juices with ohmic heating to preserve the carotenoid profile. Innov. Food Sci. Emerg. Technol. 2016, 33, 397-404. [CrossRef]

69. Tian, X.; Yu, Q.; Wu, W.; Dai, R. Inactivation of microorganisms in foods by ohmic heating: A review. J. Food Prot. 2018, 7, 1093-1107. [CrossRef]

70. Arjmandi, M.; Otón, M.; Artés, F.; Artés-Hernández, F.; Gómez, P.A.; Aguayo, E. Semi-industrial microwave treatments positively affect the quality of orange-colored smoothies. J. Food Sci. Technol. 2016, 10, 3695-3703. [CrossRef]

71. Saikia, S.; Mahnot, N.K.; Mahanta, C.L. A comparative study on the effect of conventional thermal pasteurisation, microwave and ultrasound treatments on the antioxidant activity of five fruit juices. Food Sci. Technol. Int. 2016, 22, 288-301. [CrossRef]

72. Stratakos, A.C.; Delgado-Pando, G.; Linton, M.; Patterson, M.F.; Koidis, A. Industrial scale microwave processing of tomato juice using a novel continuous microwave system. Food Chem. 2016, 190, 622-628. [CrossRef]

73. Math, R.G.; Nagender, A.; Nayani, A.S.; Satyanarayana, A. Continuous microwave processing and preservation ofacidic and non acidic juice blends. IJAFST 2014, 2, 81-90. 
74. Salazar-González, C.; Martín-González, M.F.S.; Vergara-Balderas, F.T.; López-Malo, A.; Sosa-Morales, M.E. Physical-chemical and microbiological stability during refrigerated storage of microwave-pasteurized guava nectar. Focus. Mod. Food Ind. 2014, 3, 43. [CrossRef]

75. Pérez-Grijalva, B.; Herrera-Sotero, M.; Mora-Escobedo, R.; Zebadùa-Garcià, J.C.; Silva-Hernàndez, E.; Oliart-Ros, R.; Pérez-Cruz, C.; Guzmàn-Geronimo, R. Effect of microwaves and ultrasound on bioactive compounds and microbiological quality of blackberry juice. LWT 2018, 87, 47-53. [CrossRef]

76. Gonçalves, L.C.P.; di Genova, B.M.; Dörr, F.A.; Pinto, E.; Bastos, E.L. Effect of dielectric microwave heating on the color and antiradical capacity of betanin. J. Food Eng. 2013, 118, 49-55. [CrossRef]

77. Abdullah, N. Application of thermosonication treatment in processing and production of high quality and safe-to-drink fruit juices. Agric. Agric. Sci. Procedia 2014, 2, 320-327. [CrossRef]

78. Abid, M.; Jabbar, S.; Hu, B.; Hashim, M.M.; Wu, T.; Lei, S.; Kan, M.A.; Zheng, X. Thermosonication as a potential quality enhancement technique of apple juice. Ultrason. Sonochem. 2014, 21, 984-990. [CrossRef]

79. el Kantar, S.; Boussetta, N.; Lebovka, N.I.; Foucart, F.; Rajha, H.N.; Maroun, R.G.; Louka, N.; Vorobiev, E. Pulsed electric field treatment of citrus fruits: Improvement of juice and polyphenols extraction. Innov. Food Sci. Emerg. Technol. 2018, 46, 153-161. [CrossRef]

80. Mesquita, T.C.; Schiassi, M.C.E.V.; Lago, A.M.T.; Careli-Grondim, I.; Silva, L.M.; de Azevedo Lira, N.; Carvalho, E.E.N.; de Oliveira Lima, L.C. Grape juice blends treated with gamma irradiation evaluated during storage. Radiat. Phys. Chem. 2020, 168, 108570. [CrossRef]

81. Mestry, A.P.; Mujumdar, A.S.; Thorat, B.N. Optimization of spray drying of an innovative functional food: Fermented mixed juice of carrot and watermelon. Dry. Technol. 2011, 29, 1121-1131. [CrossRef]

82. Fiorda, F.A.; de Melo Pereira, G.V.; Thomaz-Soccol, V.; Rakshit, S.K.; Pagnoncelli, M.G.B.; Vandenberghe, L.P.S.; Soccol, C.R. Microbiological, biochemical, and functional aspects of sugary kefir fermentation-A review. Food Microbiol. 2017, 66, 86-95. [CrossRef]

83. Gulitz, A.; Stadie, J.; Wenning, M.; Ehrmann, M.A.; Vogel, R.F. The microbial diversity of water kefir. Int. J. Food Microbiol. 2011, 151, 284-288. [CrossRef]

84. Gulitz, A.; Stadie, J.; Ehrmann, M.A.; Ludwig, W.; Vogel, R.F. Comparative phylobiomic analysis of the bacterial community of water kefir by $16 \mathrm{~S}$ rRNA gene amplicon sequencing and ARDRA analysis. J. Appl. Microbiol. 2013, 114, 1082-1091. [CrossRef] [PubMed]

85. Stadie, J.; Gulitz, A.; Ehrmann, M.A.; Vogel, R.F. Metabolic activity and symbiotic interactions of lactic acid bacteria and yeasts isolated from water kefir. Food Microbiol. 2013, 35, 92-98. [CrossRef]

86. Bogdan, M.; Justine, S.; Filofteia, D.; Petruta, C.; Gabriela, L.; Roxana, U.; Florentina, M. Lactic acid bacteria strains isolated from Kombucha with potential probiotic effect. Rom. Biotechnol. Lett. 2018, 23, 13592-13598.

87. Tanguler, H.; Erten, H. Occurrence and growth of lactic acid bacteria species during the fermentation of shalgam (salgam), a traditional Turkish fermented beverage. LWT-Food Sci. Technol. 2012, 46, 36-41. [CrossRef]

88. Tanguler, H.; Erten, H. Chemical and microbiological characteristics of shalgam (salgam), a traditional Turkish lactic acid fermented beverage. J. Food Qual. 2012, 35, 298-306. [CrossRef]

89. Touret, T.; Oliveira, M.; Semedo-Lemsaddek, T. Putative probiotic lactic acid bacteria isolated from sauerkraut fermentations. PLoS ONE 2018, 13, e0203501. [CrossRef]

90. Plengvidhya, V.; Breidt, F.; Lu, Z.; Fleming, H.P.; Fleming, H.P. DNA fingerprinting of lactic acid bacteria in sauerkraut fermentations. Appl. Environ. Microbiol. 2007, 73, 7697-7702. [CrossRef]

91. Wuyts, S.; van Beeck, W.; Oerlemans, E.; Wittouck, S.; Claes, I.; de Boeck, I.; Weckx, S.; Lievens, B.; de Vuyst, L.; Lebeer, S. Carrot juice fermentations as man-made microbial ecosystems dominated by lactic acid bacteria. Appl. Environ. Microbiol. 2018, 84, e00134-18. [CrossRef]

92. Puerari, C.; Magalhães, K.T.; Schwan, R.F. New cocoa pulp-based kefir beverages: Microbiological, chemical composition and sensory analysis. Food Res. Int. 2012, 48, 634-640. [CrossRef]

93. Randazzo, W.; Corona, O.; Guarcello, R.; Francesca, N.; Germanà, M.; Erten, H.; Moschetti, G.; Settanni, L. Development of new non-dairy beverages from Mediterranean fruit juices fermented with water kefir microorganisms. Food Microbiol. 2016, 54, 40-51. [CrossRef]

94. Moraru, D.; Bleoanca, I.; Segal, R. Probiotic vegetable juices. The Annals of the University Dunarea de Jos of Galati-Fascicle IV. Food Technol. 2007, 4, 87-91. 
95. Kun, S.; Rezessy-Szabó, J.M.; Nguyen, Q.D.; Hoschke, Á. Changes of microbial population and some components in carrot juice during fermentation with selected Bifidobacterium strains. Process Biochem. 2008, 43, 816-821. [CrossRef]

96. Sharma, V.; Mishra, H.N. Unstructured kinetic modeling of growth and lactic acid production by Lactobacillus plantarum NCDC 414 during fermentation of vegetable juices. LWT Food Sci. Technol. 2014, 59, 1123-1128. [CrossRef]

97. di Cagno, R.; Cardinali, G.; Minervini, G.; Antonielli, L.; Rizzello, C.G.; Ricciuti, P.; Gobetti, M. Taxonomic structure of the yeasts and lactic acid bacteria microbiota of pineapple (Ananas comosus L. Merr.) and use of autochthonous starters for minimally processing. Food Microbiol. 2010, 27, 381-389. [CrossRef]

98. Mousavi, Z.E.; Mousavi, S.M.; Razavi, S.H.; Emam-Djomeh, Z.; Kiani, H. Fermentation of pomegranate juice by probiotic lactic acid bacteria. World J. Microbiol. Biotechnol. 2011, 27, 123-128. [CrossRef]

99. Mousavi, Z.E.; Mousavi, S.M.; Razavi, S.H.; Hadinejad, M.; Emam-Djomeh, Z.; Mirzapour, M. Effect of fermentation of pomegranate juice by Lactobacillus plantarum and Lactobacillus acidophilus on the antioxidant activity and metabolism of sugars, organic acids and phenolic compounds. Food Biotechnol. 2013, 27, 1-13. [CrossRef]

100. Filannino, P.; Azzi, L.; Cavoski, I.; Vincentini, O.; Rizzello, C.; Gobbetti, M.; di Cagno, R. Exploitation of the health-promoting and sensory properties of organic pomegranate (Punica granatum L.) juice through lactic acid fermentation. Int. J. Food Microbiol. 2013, 163, 184-192. [CrossRef]

101. Valero-Cases, E.; Nuncio-Jáuregui, N.; Frutos, M.J. Influence of fermentation with different lactic acid bacteria and in vitro digestion on the biotransformation of phenolic compounds in fermented pomegranate juices. $J$. Agric. Food Chem. 2017, 65, 6488-6496. [CrossRef]

102. Rahman, N.; Xiaohong, C.; Meiqin, F.; Mingsheng, D. Characterization of the dominant microflora in naturally fermented camel milk shubat. World J. Microbiol. Biotechnol. 2009, 25, 1941-1946. [CrossRef]

103. Wang, C.-Y.; Ng, C.-C.; Su, H.; Tzeng, W.-S.; Shyu, Y.-T. Probiotic potential of noni juice fermented with lactic acid bacteria and bifidobacteria. Int. J. Food Sci. Nutr. 2009, 60, 98-106. [CrossRef]

104. di Cagno, R.; Minervini, G.; Rizzello, C.G.; de Angelis, M.; Gobbetti, M. Effect of lactic acid fermentation on antioxidant, texture, color and sensory properties of red and green smoothies. Food Microbiol. 2011, 28, 1062-1071. [CrossRef]

105. Ankolekar, C.; Pinto, M.; Greene, D.; Shetty, K. In vitro bioassay based screening of antihyperglycemia and antihypertensive activities of Lactobacillus acidophilus fermented pear juice. Innov. Food Sci. Emerg. Technol. 2012, 13, 221-230. [CrossRef]

106. Prado, F.C.; Lindner, J.D.D.; Inaba, J.; Thomaz-Soccol, V.; Brar, S.K.; Soccol, C.R. Development and evaluation of a fermented coconut water beverage with potential health benefits. J. Funct. Foods 2015, 12, $489-497$. [CrossRef]

107. Reddy, L.V.; Min, J.-H.; Wee, Y.-J. Production of probiotic mango juice by fermentation of lactic acid bacteria. Microbiol. Biotechnol. Lett. 2015, 43, 120-125. [CrossRef]

108. di Cagno, R.; Filannino, P.; Vincentini, O.; Lanera, A.; Cavoski, I.; Gobbetti, M. Exploitation of Leuconostoc mesenteroides strains to improve shelf life, rheological, sensory and functional features of prickly pear (Opuntia ficus-indica L.) fruit puree. Food Microbiol. 2016, 59, 176-189. [CrossRef]

109. Panda, S.K.; Behera, S.K.; Qaku, X.W.; Sekar, S.; Ndinteh, D.T.; Nanjundaswamy, H.M.; Ray, R.C.; Kayitesi, E. Quality enhancement of prickly pears (Opuntia sp.) juice through probiotic fermentation using Lactobacillus fermentum-ATCC 9338. LWT 2017, 75, 453-459. [CrossRef]

110. Verón, H.E.; Cano, P.G.; Fabersani, E.; Sanz, Y.; Isla, M.I.; Espinar, M.T.F.; Ponce, J.V.G.; Torres, S. Cactus pear (Opuntia ficus-indica) juice fermented with autochthonous Lactobacillus plantarum S-811. Food Funct. 2019, 10, 1085-1097. [CrossRef]

111. Hashemi, S.M.B.; Khaneghah, A.M.; Barba, F.J.; Nemati, Z.; Shokofti, S.S.; Alizadeh, F. Fermented sweet lemon juice (Citrus limetta) using Lactobacillus plantarum LS5: Chemical composition, antioxidant and antibacterial activities. J. Funct. Foods 2017, 38, 409-414. [CrossRef]

112. Kaprasob, R.; Kerdchoechuen, O.; Laohakunjit, N.; Sarkar, D.; Shetty, K. Fermentation-based biotransformation of bioactive phenolics and volatile compounds from cashew apple juice by select lactic acid bacteria. Process Biochem. 2017, 59, 141-149. [CrossRef]

113. Vivek, K.; Mishra, S.; Pradhan, R.C.; Jayabalan, R. Effect of probiotification with Lactobacillus plantarum MCC 2974 on quality of Sohiong juice. LWT 2019, 108, 55-60. [CrossRef] 
114. Cui, S.; Zhao, N.; Lu, W.; Zhao, F.; Zheng, S.; Wang, W.; Chen, W. Effect of different Lactobacillus species on volatile and nonvolatile flavor compounds in juices fermentation. Food Sci. Nutr. 2019, 7, 2214-2223. [CrossRef]

115. di Cagno, R.; Surico, R.F.; Siragusa, S.; de Angelis, M.; Paradiso, A.; Minervini, F.; de Gara, L.; Gobbetti, M. Selection and use of autochthonous mixed starter for lactic acid fermentation of carrots, French beans or marrows. Int. J. Food Microbiol. 2008, 127, 220-228. [CrossRef]

116. Subramaniyam, R.S.; Vimala, R. Solid state and submerged fermentation for the production of bioactive substances: A comparative study. Int. J. Sci. Nat. 2012, 3, 480-486.

117. Mantzourani, I.; Kazakos, S.; Terpou, A.; Alexopoulos, A.; Bezirtzoglou, E.; Bekatorou, A.; Plessas, S. Potential of the probiotic Lactobacillus plantarum ATCC 14917 strain to produce functional fermented pomegranate juice. Foods 2018, 8, 4. [CrossRef]

118. Pereira, A.L.F.; Feitosa, W.S.C.; Abreu, V.K.G.; Lemos, T.d.; Gomes, W.F.; Narain, N.; Rodrigues, S. Impact of fermentation conditions on the quality and sensory properties of a probiotic cupuassu (Theobroma grandiflorum) beverage. Food Res. Int. 2017, 100, 603-611. [CrossRef]

119. Garcia, E.F.; de Oliveira Araújo, A.; Luciano, W.A.; de Albuquerque, T.M.R.; de Oliveira Arcanjo, N.M.; Madruga, M.S.; dos Santos Lima, M.; Magnani, M.; Saarela, M.; de Souza, E.L. The performance of five fruit-derived and freeze-dried potentially probiotic Lactobacillus strains in apple, orange, and grape juices. J. Sci. Food Agric. 2018, 13, 5000-5010. [CrossRef]

120. Cirlini, M.; Ricci, A.; Galaverna, G.; Lazzi, C. Application of lactic acid fermentation to elderberry juice: Changes in acidic and glucidic fractions. LWT 2020, 118, 108779. [CrossRef]

121. Markkinen, N.; Laaksonen, O.; Nahku, R.; Kuldjärv, R.; Yang, B. Impact of lactic acid fermentation on acids, sugars, and phenolic compounds in black chokeberry and sea buckthorn juices. Food Chem. 2019, 286, 204-215. [CrossRef]

122. di Cagno, R.; Surico, R.F.; Minervini, G.; Rizello, C.G.; Lovino, R.; Servili, M.; Taticchi, A.; Urbani, S.; Gobetti, M. Exploitation of sweet cherry (Prunus avium L.) puree added of stem infusion through fermentation by selected autochthonous lactic acid bacteria. Food Microbiol. 2011, 28, 900-909. [CrossRef]

123. Gao, H.; Wen, J.-J.; Hu, J.-L.; Nie, Q.-X.; Chen, H.-H.; Nie, S.-P.; Xiong, T.; Xie, M.-Y. Momordica charantia juice with Lactobacillus plantarum fermentation: Chemical composition, antioxidant properties and aroma profile. Food Biosci. 2019, 29, 62-72. [CrossRef]

124. Kwaw, E.; Ma, Y.; Tchabo, W.; Apaliya, M.T.; Wu, M.; Sackey, A.S.; Xiao, L.; Tahir, H.E. Effect of Lactobacillus strains on phenolic profile, color attributes and antioxidant activities of lactic-acid-fermented mulberry juice. Food Chem. 2018, 250, 148-154. [CrossRef]

125. Li, Z.; Teng, J.; Lyu, Y.; Hu, X.; Zhao, Y.; Wang, M. Enhanced antioxidant activity for apple juice fermented with Lactobacillus plantarum ATCC14917. Molecules 2018, 24, 51. [CrossRef]

126. Yan, Y.; Zhang, F.; Chai, Z.; Liu, M.; Battino, M.; Meng, X. Mixed fermentation of blueberry pomace with $L$. rhamnosus GG and L. plantarum-1: Enhance the active ingredient, antioxidant activity and health-promoting benefits. Food Chem. Toxicol. 2019, 131, 110541. [CrossRef]

127. Hur, S.J.; Lee, S.Y.; Kim, Y.-C.; Choi, I.; Kim, G.-B. Effect of fermentation on the antioxidant activity in plant-based foods. Food Chem. 2014, 160, 346-356. [CrossRef]

128. Ye, J.-H.; Huang, L.-Y.; Terefe, N.S.; Augustin, M.A. Fermentation-based biotransformation of glucosinolates, phenolics and sugars in retorted broccoli puree by lactic acid bacteria. Food Chem. 2019, 286, 616-623. [CrossRef]

129. Ricci, A.; Cirlini, M.; Calani, L.; Bernini, V.; Neviani, E.; del Rio, D.; Galaverna, G.; Lazzi, C. In vitro metabolism of elderberry juice polyphenols by lactic acid bacteria. Food Chem. 2019, 276, 692-699. [CrossRef]

130. Scalbert, A.; Manach, C.; Morand, C.; Rémésy, C.; Jiménez, L. Dietary polyphenols and the prevention of diseases. Crit. Rev. Food Sci. Nutr. 2005, 45, 287-306. [CrossRef]

131. Costa, C.; Tsatsakis, A.; Mamoulakis, C.; Teodoro, M.; Briguglio, G.; Caruso, E.; Tsoukalas, D.; Margina, D.; Dardiotis, E.; Kouretas, D.; et al. Current evidence on the effect of dietary polyphenols intake on chronic diseases. Food Chem. Toxicol. 2017, 110, 286-299. [CrossRef]

132. Silva, F.; Borges, F.; Guimarães, C.; Lima, J.; Matos, C.; Reis, S. Phenolic acids and derivatives: Studies on the relationship among structure, radical scavenging activity, and physicochemical parameters. J. Agric. Food Chem. 2000, 48, 2122-2126. [CrossRef] 
133. Huang, J.; de Paulis, T.; May, J.M. Antioxidant effects of dihydrocaffeic acid in human EA.hy 926 endothelial cells. J. Nutr. Biochem. 2004, 12, 722-729. [CrossRef]

134. Lin, D.; Xiao, M.; Zhao, J.; Li, Z.; Xing, B.; Li, X.; Kong, M.; Li, L.; Zhang, Q.; Liu, Y.; et al. An overview of plant phenolic compounds and their importance in human nutrition and management of type 2 diabetes. Molecules 2016, 21, 10. [CrossRef]

135. Nagappan, H.; Pee, P.P.; Kee, S.H.Y.; Ow, J.T.; Yan, S.W.; Chew, L.Y.; Kong, K.W. Malaysian brown seaweeds Sargassum siliquosum and Sargassum polycystum: Low density lipoprotein (LDL) oxidation, angiotensin converting enzyme (ACE), $\alpha$-amylase, and $\alpha$-glucosidase inhibition activities. Food Res. Int. 2017, 99, 950-958. [CrossRef]

136. Tan, Y.; Chang, S.K.C.; Zhang, Y. Comparison of $\alpha$-amylase, $\alpha$-glucosidase and lipase inhibitory activity of the phenolic substances in two black legumes of different genera. Food Chem. 2017, 214, 259-268. [CrossRef]

137. Zhang, L.; Hogan, S.; Li, J.; Sun, S.; Canning, C.; Zheng, S.J.; Zhou, K. Grape skin extract inhibits mammalian intestinal $\alpha$-glucosidase activity and suppresses postprandial glycemic response in streptozocin-treated mice. Food Chem. 2011, 126, 466-471. [CrossRef]

138. He, Q.; Lv, Y.; Yao, K. Effects of tea polyphenols on the activities of $\alpha$-amylase, pepsin, trypsin and lipase. Food Chem. 2007, 101, 1178-1182. [CrossRef]

139. Kostinek, M.; Spechta, I.; Edward, V.A.; Schillinger, U.; Hertel, C.; Holzapfel, W.H.; Franza, C.M.A.P. Diversity and technological properties of predominant lactic acid bacteria from fermented cassava used for the preparation of Gari, a traditional African food. Syst. Appl. Microbiol. 2005, 28, 527-540. [CrossRef]

140. Kohajdová, Z.; Karovičová, J. Fermentation of cereals for specific purpose. J. Food Nutr. Res. 2007, 46, 51-57.

141. Roger, T.; Léopold, T.N.; Funtong, M.C.M. Nutritional properties and antinutritional factors of corn paste (kutukutu) fermented by different strains of lactic acid bacteria. Int. J. Food Sci. 2015, 2015, 1-13. [CrossRef]

142. Ripari, V. Techno-functional role of exopolysaccharides in cereal-based, yogurt-like beverages. Beverages 2019, 5, 16. [CrossRef]

143. Juvonen, R.; Honkapää, K.; Maina, N.H.; Shi, Q.; Viljanen, K.; Maaheimo, H.; Virkki, L.; Tenkanen, M.; Lantto, R. The impact of fermentation with exopolysaccharide producing lactic acid bacteria on rheological, chemical and sensory properties of pureed carrots (Daucus carota L.). Int. J. Food Microbiol. 2015, 207, 109-118. [CrossRef]

144. Lynch, K.M.; Zannini, E.; Coffey, A.; Arendt, E.K. Lactic acid bacteria exopolysaccharides in foods and beverages: Isolation, properties, characterization, and health benefits. Annu. Rev. Food Sci. Technol. 2018, 9, 155-176. [CrossRef]

145. Zhang, L.; Liu, C.; Li, D.; Zhao, Y.; Zhang, X.; Zeng, X.; Yang, Z.; Li, S. Antioxidant activity of an exopolysaccharide isolated from Lactobacillus plantarum C88. Int. J. Biol. Macromol. 2013, 54, 270-275. [CrossRef]

146. Pan, D.; Mei, X. Antioxidant activity of an exopolysaccharide purified from Lactococcus lactis subsp. lactis 12. Carbohydr. Polym. 2010, 80, 908-914. [CrossRef]

147. Liu, C.-F.; Tseng, K.-C.; Chiang, S.-S.; Lee, B.-H.; Hsu, W.-H.; Pan, T.-M. Immunomodulatory and antioxidant potential of Lactobacillus exopolysaccharides. J. Sci. Food Agric. 2011, 91, 2284-2291. [CrossRef]

148. Caggianiello, G.; Kleerebezem, M.; Spano, G. Exopolysaccharides produced by lactic acid bacteria: From health-promoting benefits to stress tolerance mechanisms. Appl. Microbiol. Biotechnol. 2016, 100, 3877-3886. [CrossRef]

149. Rivera-Espinoza, Y.; Gallardo-Navarro, Y. Non-dairy probiotic products. Food Microbiol. 2010, $27,1-11$. [CrossRef]

150. Pinto, S.S.; Verruck, S.; Vieira, C.R.W.; Prudêncio, E.S.; Amante, E.R.; Amboni, R.D.M.C. Influence of microencapsulation with sweet whey and prebiotics on the survival of Bifidobacterium-BB-12 under simulated gastrointestinal conditions and heat treatments. LWT-Food Sci. Technol. 2015, 64, 1004-1009. [CrossRef]

151. Chaudhary, A. Probiotic fruit and vegetable juices: Approach towards a healthy gut. Int. J. Curr. Microbiol. Appl. Sci. 2019, 8, 1265-1279. [CrossRef]

152. Parvez, S.; Malik, K.A.; Kang, S.A.; Kim, H.-Y. Probiotics and their fermented food products are beneficial for health. J. Appl. Microbiol. 2006, 100, 1171-1185. [CrossRef]

153. Nagpal, R.; Kumar, A.; Kumar, M.; Behare, P.V.; Jain, S.; Yadav, H. Probiotics, their health benefits and applications for developing healthier foods: A review. FEMS Microbiol. Lett. 2012, 334, 1-15. [CrossRef] 
154. Liu, D.-M.; Guo, J.; Zeng, X.-A.; Sun, D.-W.; Brennan, C.S.; Zhou, Q.-X.; Zhou, J.-S. The probiotic role of Lactobacillus plantarum in reducing risks associated with cardiovascular disease. Int. J. Food Sci. Technol. 2017, 52, 127-136. [CrossRef]

155. Wuyts, S.; van Beeck, W.; Allonsius, C.N.; van den Broek, M.F.; Lebeer, S. Applications of plant-based fermented foods and their microbes. Curr. Opin. Biotechnol. 2020, 61, 45-52. [CrossRef] [PubMed]

156. Pereira-Caro, G.; Oliver, C.M.; Weerakkody, R.; Singh, T.; Conlon, M.; Borges, G.; Sanguansri, L.; Lockett, T.; Roberts, S.A.; Augustin, A.C.M.A. Chronic administration of a microencapsulated probiotic enhances the bioavailability of orange juice flavanones in humans. Free Radic. Biol. Med. 2015, 84, 206-214. [CrossRef]

157. Valero-Cases, E.; Roy, N.C.; Frutos, M.J.; Anderson, R.C. Influence of the fruit juice carriers on the ability of Lactobacillus plantarum DSM20205 to improve in vitro intestinal barrier integrity and its probiotic properties. J. Agric. Food Chem. 2017, 65, 5632-5638. [CrossRef]

158. Ren, T.; Zhu, J.; Zhu, L.; Cheng, M. The combination of blueberry juice and probiotics ameliorate non-alcoholic steatohepatitis (NASH) by affecting SREBP-1c/PNPLA-3 pathway via PPAR- $\alpha$. Nutrients 2017, 9, 198. [CrossRef]

159. Gaanappriya, M.; Guhankumar, P.; Kiruththica, V.; Santhiya, N.; Anita, S. Probiotication of fruit juices by Lactobacillus acidophilus. Int. J. Adv. Biotechnol. Res. 2013, 4, 72-77.

160. Shah, N.P.; Ding, W.K.; Fallourd, M.J.; Leyer, G. Improving the stability of probiotic bacteria in model fruit juices using vitamins and antioxidants. J. Food Sci. 2010, 75, 5. [CrossRef]

161. Rúa, J.; López-Rodríguez, I.; Sanz, J.; García-Fernández, M.C.; del Valle, M.P.; García-Armesto, M.R. Improving functional properties of 'Piel de Sapo' melon juice by addition of a Lippia citriodora natural extract and probiotic-type lactic acid bacteria. LWT 2018, 96, 75-81. [CrossRef]

162. Haffner, F.B.; Pasc, A. Freeze-dried alginate-silica microparticles as carriers of probiotic bacteria in apple juice and beer. LWT 2018, 91, 175-179. [CrossRef]

163. Vivek, K.; Mishra, S.; Pradhan, R.C. Characterization of spray dried probiotic Sohiong fruit powder with Lactobacillus plantarum. LWT 2020, 117, 108699. [CrossRef]

164. Tsen, J.-H.; Lin, Y.-P.; Huang, H.-Y.; King, V.A.-E. Studies on the fermentation of tomato juice by using K-carrageenan immobilized Lactobacillus acidophilus. J. Food Process. Preserv. 2008, 32, 178-189. [CrossRef]

165. Olivares, A.; Soto, C.; Caballero, E.; Altamirano, C. Survival of microencapsulated Lactobacillus casei (prepared by vibration technology) in fruit juice during cold storage. Electron. J. Biotechnol. 2019, 42, 42-48. [CrossRef]

166. Šárka, H.; Kristýna, R.; Kristina, B.; Iveta, K.; Marcela, S. Fruit juices with probiotics-New type of functional foods. Czech J. Food Sci. 2018, 36, 284-288. [CrossRef]

167. Sivudu, S.N.; Ramesh, B.; Umamahesh, K.; Vijaya Sarathi Reddy, O. Probiotication of tomato and carrot juices for shelf-life enhancement using micro-encapsulation. J. Food Biosci. Technol. 2016, 6, 13-22.

168. Dias, C.O.; de Almeida, J.D.S.O.; Pinto, S.S.; de Oliveira Santana, F.C.; Verruck, S.; Müller, C.M.O.; Schwinden Prudêncio, E.; de Mello Castanho Amboni, R.D. Development and physico-chemical characterization of microencapsulated bifidobacteria in passion fruit juice: A functional non-dairy product for probiotic delivery. Food Biosci. 2018, 24, 26-36. [CrossRef]

169. Santos, E.; Andrade, R.; Gouveia, E. Utilization of the pectin and pulp of the passion fruit from Caatinga as probiotic food carriers. Food Biosci. 2017, 20, 56-61. [CrossRef]

170. Miranda, R.F.; de Paula, M.M.; da Costa, G.M.; Barão, C.E.; da Silva, A.C.R.; Raices, R.S.L.; Gomes, R.G.; Pimentel, T.C. Colombo Pimentel, Orange juice added with L. casei: Is there an impact of the probiotic addition methodology on the quality parameters? LWT 2019, 106, 186-193. [CrossRef]

171. Gerardi, C.; Tristezza, M.; Giordano, L.; Rampino, P.; Perrotta, C.; Baruzzi, F.; Capozzi, V.; Mita, G.; Grieco, F. Exploitation of Prunus mahaleb fruit by fermentation with selected strains of Lactobacillus plantarum and Saccharomyces cerevisiae. Food Microbiol. 2019, 84, 103262. [CrossRef]

172. Lu, Y.; Putra, S.D.; Liu, S.-Q. A novel non-dairy beverage from durian pulp fermented with selected probiotics and yeast. Int. J. Food Microbiol. 2018, 265, 1-8. [CrossRef]

173. Ávila, M.; Hidalgo, M.; Sánchez-Moreno, C.; Pelaez, C.; Requena, T.; de Pascual-Teresa, S. Bioconversion of anthocyanin glycosides by Bifidobacteria and Lactobacillus. Food Res. Int. 2009, 42, 1453-1461. [CrossRef]

174. Esteban-Torres, M.; Landete, J.M.; Reverón, I.; Santamaría, L.; de las Rivas, B.; Muñoz, R. A Lactobacillus plantarum esterase active on a broad range of phenolic esters. Appl. Environ. Microbiol. 2015, 81, 3235-3242. [CrossRef] [PubMed] 
175. Santamaría, L.; Reverón, I.; de Felipe, F.L.; de las Rivas, B.; Muñoz, R. Unravelling the reduction pathway as an alternative metabolic route to hydroxycinnamate decarboxylation in Lactobacillus plantarum. Appl. Environ. Microbiol. 2018, 84, 15. [CrossRef] [PubMed]

176. Santamaría, L.; Reverón, I.; de Felipe, F.L.; de las Rivas, B.; Muñoz, R. Ethylphenol formation by Lactobacillus plantarum: Identification of the enzyme involved in the reduction of vinylphenols. Appl. Environ. Microbiol. 2018, 84, 17. [CrossRef] [PubMed]

177. Mozzi, F.; Ortiz, M.E.; Bleckwedel, J.; de Vuyst, L.; Pescuma, M. Metabolomics as a tool for the comprehensive understanding of fermented and functional foods with lactic acid bacteria. Food Res. Int. 2013, 54, 1152-1161. [CrossRef]

178. Singh, D.; Lee, S.; Lee, C.H. Metabolomics for empirical delineation of the traditional Korean fermented foods and beverages. Trends Food Sci. Technol. 2017, 61, 103-115. [CrossRef]

179. Tomita, S.; Saito, K.; Nakamura, T.; Sekiyama, Y.; Kikuchi, J. Rapid discrimination of strain-dependent fermentation characteristics among Lactobacillus strains by NMR-based metabolomics of fermented vegetable juice. PLoS ONE 2017, 12, e0182229. [CrossRef] [PubMed]

180. Chun, B.H.; Kim, K.H.; Jeon, H.H.; Lee, S.H.; Jeon, C.O. Pan-genomic and transcriptomic analyses of Leuconostoc mesenteroides provide insights into its genomic and metabolic features and roles in kimchi fermentation. Sci. Rep. 2017, 7, 11504. [CrossRef]

181. Filannino, P.; di Cagno, R.; Gobbetti, M. Metabolic and functional paths of lactic acid bacteria in plant foods: Get out of the labyrinth. Curr. Opin. Biotechnol. 2018, 49, 64-72. [CrossRef]

(C) 2020 by the authors. Licensee MDPI, Basel, Switzerland. This article is an open access article distributed under the terms and conditions of the Creative Commons Attribution (CC BY) license (http://creativecommons.org/licenses/by/4.0/). 